\title{
History of Nonalcoholic Fatty Liver Disease
}

\author{
Amedeo Lonardo ${ }^{1, *(\mathbb{D}}$, Simona Leoni ${ }^{2}$, Khalid A. Alswat ${ }^{3}$ and Yasser Fouad ${ }^{4}(\mathbb{D}$ \\ 1 Ospedale Civile di Baggiovara, UOC Medicina Metabolica, Dipartimento di Medicina Interna Generale, \\ d’Urgenza e post Acuzie, Azienda Ospedaliero-Universitaria di Modena, Via Giardini 1135, \\ 41125 Modena, Italy \\ 2 Internal Medicine Unit, Department of Digestive Diseases, S.Orsola-Malpighi Hospital, Via Massarenti 9, \\ 40136 Bologna, Italy; simona.leoni@aosp.bo.it \\ 3 Liver Research Center, Department of Medicine, College of Medicine, King Saud University, Riyadh 11322, \\ Saudi Arabia; kalswat@ksu.edu.sa \\ 4 Department of Gastroenterology, Hepatology and Endemic Medicine, Faculty of Medicine, Minia University, \\ Minya 19111, Egypt; yasserfouad10@yahoo.com \\ * Correspondence: a.lonardo@libero.it or lonardo.amedeo@aou.mo.it
}

Received: 21 July 2020; Accepted: 12 August 2020; Published: 16 August 2020

Abstract: Based on the assumption that characterizing the history of a disease will help in improving practice while offering a clue to research, this article aims at reviewing the history of nonalcoholic fatty liver disease (NAFLD) in adults and children. To this end, we address the history of NAFLD histopathology, which begins in 1980 with Ludwig's seminal studies, although previous studies date back to the 19th century. Moreover, the principal milestones in the definition of genetic NAFLD are summarized. Next, a specific account is given of the evolution, over time, of our understanding of the association of NAFLD with metabolic syndrome, spanning from the outdated concept of "NAFLD as a manifestation of the Metabolic Syndrome", to the more appropriate consideration that NAFLD has, with metabolic syndrome, a mutual and bi-directional relationship. In addition, we also report on the evolution from first intuitions to more recent studies, supporting NAFLD as an independent risk factor for cardiovascular disease. This association probably has deep roots, going back to ancient Middle Eastern cultures, wherein the liver had a significance similar to that which the heart holds in contemporary society. Conversely, the notions that NAFLD is a forerunner of hepatocellular carcinoma and extra-hepatic cancers is definitely more modern. Interestingly, guidelines issued by hepatological societies have lagged behind the identification of NAFLD by decades. A comparative analysis of these documents defines both shared attitudes (e.g., ultrasonography and lifestyle changes as the first approaches) and diverging key points (e.g., the threshold of alcohol consumption, screening methods, optimal non-invasive assessment of liver fibrosis and drug treatment options). Finally, the principal historical steps in the general, cellular and molecular pathogenesis of NAFLD are reviewed. We conclude that an in-depth understanding of the history of the disease permits us to better comprehend the disease itself, as well as to anticipate the lines of development of future NAFLD research.

Keywords: cryptogenic cirrhosis; genetics; guidelines; history of medicine; hepatocellular carcinoma; histopathology; insulin resistance; MAFLD; metabolic syndrome; molecular pathogenesis; NASH; pediatric NAFLD; steatosis.

\section{Background}

\subsection{Definition}

Formerly named nonalcoholic fatty liver disease (NAFLD), the spectrum of fatty liver disorders not resulting from alcohol abuse, viral, autoimmune, drug-induced and genetic etiologies, has recently 
been renamed metabolic (dysfunction) associated fatty liver disease (MAFLD) [1]. In agreement with a consistent line of opinions, this novel nomenclature correctly points out the "positive" determinants of the disease, namely the close association with metabolic disorders, rather than defining it for what it is not (i.e., nonalcoholic) [2]. Table 1 [1,3-22] lists some of the definitions that have either been proposed or used to designate NAFLD/MAFLD over time.

\subsection{Burden}

Obesity is an independent predictor of disease, accounting for the incremental changes in NAFLD over time in the USA [23]. However, NAFLD is not only common in USA and Europe, where it affects roughly one quarter of the general population [24]: in certain areas of the world, such as in South America, urban India and Sri Lanka, Israel and Turkey, prevalence rates of NAFLD range from $30 \%$ to $48 \%$ [25]. As a result of its epidemic distribution, NAFLD has become a major clinical and public health issue worldwide [26-31].

\subsection{Aim}

Given that the clue to future research is deeply eradicated in NAFLD history [32], and that understanding its historical developments over time will promote optimal practice, a group of researchers worked together to identify the principal steps in the study of NAFLD in adults and children.

The history of NAFLD includes myriads of milestone advances and innumerable major breakthroughs which, collectively, would be virtually impossible to review. Therefore, four major areas of interest have been identified: histopathology; clinical correlates-natural course; guidelines, and general, cellular and molecular pathogenesis. Although these areas are mutually overlapping, this schematic partitioning serves to provide a more legible analysis. 
Table 1. Names used in the past to designate NAFLD and MAFLD [1,3-21].

\begin{tabular}{|c|c|c|}
\hline Year-Author [Ref] & Name & Comment \\
\hline 1845-Addison [3] & Fatty Liver & $\begin{array}{l}\text { Thomas Addison, better known by the eponymic disease of cortisol deficiency, was first in } \\
\text { reporting alcohol-induced liver histology changes. }\end{array}$ \\
\hline 1938-Connor [4] & Fatty infiltration of the liver & $\begin{array}{l}\text { This author clearly pinpoints that steatosis, irrespective of whether owing to alcoholic } \\
\text { etiology or due to diabetes, is a precursor of cirrhosis in animal studies as well as in humans. }\end{array}$ \\
\hline 1964-Dianzani [5] & Hepatic steatosis & $\begin{array}{l}\text { This contribution, written in Italian, is the first of three highlighting the pathogenic } \\
\text { mechanisms eventually conducive to the accumulation of intra-hepatic fat. }\end{array}$ \\
\hline 1979_Adler \& Schaffner [6] & Fatty liver hepatitis and cirrhosis & $\begin{array}{l}\text { In the obese, liver histology changes resemble those induced by alcohol and jejuno-ileal } \\
\text { bypass suggesting a common denominator in these three conditions. }\end{array}$ \\
\hline 1980—Ludwig [7] & Nonalcoholic steatohepatitis (NASH) & $\begin{array}{l}\text { In this seminal report of } 20 \text { patients whose liver biopsy specimens exhibited striking fatty } \\
\text { and necro-inflammatory changes, Mallory bodies, fibrosis and cirrhosis, the name "NASH" is } \\
\text { coined. The cohort featured a high prevalence of female sex; most patients were obese, many } \\
\text { had T2D, gallstones and thyroid disease. }\end{array}$ \\
\hline 1985-Batman [8] & Diabetic hepatitis & $\begin{array}{l}\text { Report of a nonalcoholic patient with a family history of both diabetes and chronic liver } \\
\text { disease in whom liver histology resembling alcoholic hepatitis, asymptomatic chronic } \\
\text { progressive hepatomegaly and mild alterations of liver tests preceded incident glucose } \\
\text { intolerance by years. }\end{array}$ \\
\hline 1986-Schaffner \& Thaler [9] & Nonalcoholic Fatty Liver Disease & This review article was first in using the name nonalcoholic fatty liver disease. \\
\hline 1988-Diehl, Goodman, Ishak [10] & $\begin{array}{l}\text { Alcohol-like liver disease in the } \\
\text { non-alcoholic }\end{array}$ & $\begin{array}{l}\text { Liver histology features of alcoholic and nonalcoholic individuals were often } \\
\text { indistinguishable based on histology alone suggesting that liver histology does not explain } \\
\text { the clinical differences between these individuals and raising the possibility that either } \\
\text { nutritional or hormonal factors account for alcohol-like histological changes in both } \\
\text { conditions. }\end{array}$ \\
\hline 1995-Lonardo [11] & Bright liver syndrome & $\begin{array}{l}\text { This was meant to be an umbrella definition grouping together (hence "syndrome") the } \\
\text { conditions observed in individuals with a "bright liver echopattern" at ultrasonography. The } \\
\text { associations with gallstones and atherosclerosis are highlighted. }\end{array}$ \\
\hline 1999-Mendler [12] & IRHIO & $\begin{array}{l}\text { Probably NAFLD, such as is found in a population with a high prevalence of hereditary } \\
\text { hemochromatosis }\end{array}$ \\
\hline $\begin{array}{l}\text { 2002-Neuschwander-Tetri and } \\
\text { Caldwell, on behalf of AASLD [13] }\end{array}$ & MESH & $\begin{array}{l}\text { The authors summarize the presentations and discussions at an AASLD-sponsored Single } \\
\text { Topic Conference on fatty liver disorders held in September, } 2002 .\end{array}$ \\
\hline
\end{tabular}


Table 1. Cont.

\begin{tabular}{|c|c|c|}
\hline Year-Author [Ref] & Name & Comment \\
\hline 2002_Dixon [14] & MSSH & $\begin{array}{l}\text { The disease entity of NASH includes many putative factors. These authors propose to } \\
\text { enucleate a condition which is clearly related to the MetS, hence the name MSSH. }\end{array}$ \\
\hline 2002-Farrell [15] & NASH & $\begin{array}{l}\text { The author discusses the prevalence, importance and risk factors of NAFLD in the } \\
\text { Asia-Pacific region. A proposed classification of weight by body mass index for Asians is } \\
\text { devised in addition to a practical approach to the diagnosis of NAFLD. }\end{array}$ \\
\hline 2004-Brunt [16] & NASH & $\begin{array}{l}\text { The author discusses the prevalence studies and the pathophysiology of NAFLD including } \\
\text { the challenges of pediatric NASH and NASH-related cirrhosis. }\end{array}$ \\
\hline $\begin{array}{l}\text { 2005-Loria, Lonardo and Carulli } \\
\text { [17] }\end{array}$ & Metabolic (fatty) liver disorders & $\begin{array}{l}\text { The reasons why NAFLD should be renamed are extensively discussed. It is proposed that a } \\
\text { positive criterion being introduced in the name would create significant benefits. It is also } \\
\text { highlighted that fatty changes disappear when cirrhosis develops explaining the superior } \\
\text { importance of "metabolic/insulin resistance" over "fatty" in the qualification of this } \\
\text { syndromic liver disorder. }\end{array}$ \\
\hline 2009_Ratziu [18] & Metabolic fatty liver disease & $\begin{array}{l}\text { This position paper strongly argues for a change in NAFLD nomenclature by dropping the } \\
\text { "negative" definition ("nonalcoholic") and recognizing the key role of IR. }\end{array}$ \\
\hline 2009—Brunt [19] & Metabolic fatty liver disease & $\begin{array}{l}\text { The definitions of NAFLD/NASH remain based on the "non-association" with alcoholic } \\
\text { etiology rather than with the recognition of those truly associated conditions. }\end{array}$ \\
\hline 2011—Balmer and Dufour [20] & MAFLD & $\begin{array}{l}\text { Based on the recognition that AFLD and NAFLD share the same liver histology and often } \\
\text { also metabolic alterations, the authors believe that MAFLD might describe both patient } \\
\text { populations more accurately while depicting the key pathophysiological features. }\end{array}$ \\
\hline 2017—Bellentani and Tiribelli [21] & $\begin{array}{l}\text { NAFLD and NASH could be } \\
\text { collectively named MAFL. } \\
\text { MAFL associated with liver injury } \\
\text { may be designed as MASH, or DCH. }\end{array}$ & $\begin{array}{l}\text { The authors list the several designations to identify NAFLD, such as BASH, CASH, DASH or } \\
\text { GASH. They suggest progressing from a negative to a positive definition. }\end{array}$ \\
\hline 2019-Eslam, Sanyal \& George [22] & MAFLD & $\begin{array}{l}\text { Proposal of more accurate nomenclature of disease. This study lays the foundation for the } \\
\text { work of an International panel of experts published the following year. }\end{array}$ \\
\hline $\begin{array}{l}\text { 2020-Eslam, Sanyal \& George on } \\
\text { behalf of the International Consensus } \\
\text { Panel [1] }\end{array}$ & MAFLD & $\begin{array}{l}\text { An International panel of experts from } 22 \text { countries proposes a novel definition of disease } \\
\text { which is based on hepatic steatosis, associated with one out of three criteria: } \\
\text { overweight/obesity, T2D, metabolic derangement. }\end{array}$ \\
\hline
\end{tabular}




\section{History of NAFLD Histopathology}

\subsection{Before 1980}

Addison was the first to describe fatty liver in 1836 [3]. Subsequently, for decades, pathologists pinpointed the similarities of liver histology changes seen in diabetic and morbidly obese individuals with those of alcoholics. In 1838, in autopsy specimens, the pathologist Rokitansky documented hepatic fat accumulation that might be causative of cirrhosis [33]. In 1884, Pepper described fatty infiltration of the liver in a diabetic patient [34]. In 1885, Bartholow reported a potential association between obesity and fatty liver [35]. In 1938, Connor described fatty liver infiltration that might led to the development of cirrhosis in diabetics. He reported on two cases of bleeding esophageal varices (one case was fatal owing to severe hemorrhage) in patients with diabetes and fatty liver. Perilobular fibrosis described in these patients was explained by both mechanical factors and tissue anoxia [4]. In 1958, Westwater and Feiner reported the histological findings of fatty infiltration of the liver in obese patients [36]. In 1962, Thaler added a further clinical and pathological description of the disease [36]. Since then, several reports in the 1950s-1970s pathologically documented the occurrence of fatty liver disease in obese and diabetic subjects [36].

\subsection{0 and Beyond}

In 1980, the term nonalcoholic steatohepatitis (NASH) was coined by Ludwig et al., to describe the progressive form of fatty liver disease histologically resembling alcoholic steatohepatitis though observed in patients who denied any alcohol abuse [7]. The majority of patients were obese women, and many were diabetic. The histopathological changes included lobular hepatitis, inflammatory infiltrates, Mallory bodies and focal necrosis with evidence of fibrosis in most specimens and cirrhosis in three patients [7]. In 1983, Moran et al., extended these findings to obese children in whom steatohepatitis presented with abnormal liver enzymes and non-specific symptoms [37]. Schaffner and Thaler were first to use the name "nonalcoholic fatty liver disease" in 1986 [9].

Over time, several histological scores for disease assessment have been developed and, currently, at least four main semi-quantitative scoring systems for the assessment of the histological features of NAFLD are available. The NAFLD activity score, comprised 14 histological features, 4 of which were evaluated semi-quantitatively: steatosis (0-3), lobular inflammation (0-2), hepatocellular ballooning $(0-2)$, and fibrosis (0-4). Another nine features were recorded as present-or-absent. This score was developed by the NASH Clinical Research Network (NASH-CRN) [38]. The "Fatty Liver Inhibition of Progression (FLIP)" algorithm, which was developed by the FLIP consortium, is based on a scoring system (including steatosis, ballooning and lobular inflammation), the SAF score (steatosis, activity, fibrosis) [39]. The so called "Brunt" system score included ten histological variables to determine the inflammatory grading with a score for staging fibrosis [40]. Finally, the pediatric NAFLD histological score was based on the evaluation of steatosis, ballooning, portal inflammation and lobular inflammation [41].

There is general consensus that a constellation of histological features is required for the histopathological identification of adult NASH, including steatosis, ballooning, lobular inflammation and perisinusoidal fibrosis. In contrast, there is no universal agreement among liver pathologists regarding the essential criteria for the diagnosis of NASH. In addition, compared to other histological features, such as fibrosis, the histological diagnosis of NASH exhibits a large inter- and intra-observer variability and sampling error, which is reflected by the widely ranging prevalence of NASH, from $1.4 \%$ to $20 \%$ of liver biopsies [42]. This lack of reliability in the assessment of NASH may also affect NASH trials, by introducing patients who do not meet entry criteria, misclassifying fibrosis subgroups, and attenuating apparent treatment effects [43]. For instance, in the sole Phase 3 clinical trial for NAFLD to date that showed significant results, obeticholic acid failed to demonstrate a significant impact on NASH resolution, though it had a significant effect on fibrosis [44,45]. Future studies should identify reliable non-invasive tests for the prediction of NASH. 
In this context, a panel of international experts from 22 countries across the globe recently proposed to abandon the simple and inaccurate dichotomous classification into ' $\mathrm{NASH}$ ' versus 'non-NASH'. These authors, aiming at improving the assessment of severity of disease, argue that the gamut of liver lesions should rather be assessed as a continuous and dynamic variable, such as is done in other diseases, therefore minimizing the negative implication of this conceptually wrong dichotomization $[1,46]$.

Interestingly, steatosis may not persist during the progression of NAFLD, and rather may vanish in advanced cases of NAFLD-cirrhosis. This may lead to the blurring of the distinction between cryptogenic cirrhosis versus burned-out NAFLD-cirrhosis. Recently, various reports have demonstrated that features and the course of the two entities are different $[47,48]$. Unfortunately, this group of patients is usually excluded from clinical trials, as they lack the key criterion of "presence of steatosis". The international consensus panel clarified this aspect by proposing that patients with cirrhosis, even in the absence of typical histological features of steatohepatitis, should be considered as MAFLD-related cirrhosis if they meet at least one of the following criteria: past or present evidence of metabolic dysregulation (according to MAFLD criteria), with either documentation of MAFLD in previous biopsy or steatosis by imaging techniques $[17,46]$.

\subsection{History of Genetic NAFLD}

NAFLD pathobiology has a high level of inheritability, and the genetic determinants of disease development and progression are increasingly recognized. Similar to other complex diseases, the genetic studies of NAFLD have passed through two major stages: the candidate gene approach first, followed by genome-wide association studies (GWAS) [49]. The former approach is driven by hypotheses based on the a priori knowledge of the biological functions regulated by candidate genes. Numerous variants of genes which can govern (therefore candidates) either susceptibility to or progression of NAFLD have been identified using this approach [50]. However, most of these studies were underpowered owing to small size, which has been reflected by the inconsistency of published reports.

The first GWAS in hepatology aimed at investigating the genetic basis of susceptibility to NAFLD dates back to 2008 [51]. Since then, hypothesis-free method-based discoveries, including GWAS, whole-genome and whole-exome sequencing have become the default methodology to determine genotype-phenotype associations. In these tests, correlations are performed between large numbers of single-nucleotide polymorphisms (SNPs), up to hundreds of thousands to over a million across the genome, and a single trait. This has led to an advancement in our understanding of the genetic underpinnings of NAFLD, with at least five variants in different genes having been robustly associated with the susceptibility to development and progression of NAFLD. These include: patatin-like phospholipase domain-containing protein 3 (PNPLA3), transmembrane 6 superfamily member 2 (TM6SF2), glucokinase regulator (GCKR), and hydroxysteroid 17 $\beta$ - dehydrogenase (HSD17B13) [51-55]. In addition, this approach helped in characterizing the genetic basis shared by NAFLD with other liver diseases as well as with other metabolic disorders, by identifying a role for variants in membrane bound O-acyltransferase domain-containing 7 (MBOAT7) [56-58], IFNL3/IFNL4 [59,60] and FNDC5 in NAFLD [61]. That said, it remains uncertain whether "genetic NAFLD" is perfectly equivalent to "metabolic NAFLD" as far as, for example, cardiovascular risk is concerned [62].

In the post-GWAS era, we are currently harvesting the benefits of the GWAS discoveries, including the incorporation of genetics in diagnostic and prognostic models $[63,64]$, with an emerging role for polygenic scores $[65,66]$. In addition, genetic findings are well positioned to lead the path for modernization of the process of drug development, with recent evidence suggesting that a drug target with a genetic link has a double likelihood of success in clinical trials compared to other drugs that lack such a link $[67,68]$. Finally, the era of phenome-wide association study (PheWAS), moving from investigating a single phenotype to considering multiple phenotypes, is emerging [52]. 


\section{History of Clinical Correlates and Natural Course of NAFLD}

\subsection{From the Metabolic Syndrome to NAFLD}

The history of the metabolic syndrome is intriguing and complex. The first recognition of obesity and visceral adiposity as cardiovascular risk factors probably dates back to almost 2.400-260 years ago, respectively (Table 2 [69-98] and Figure 1 [73]).
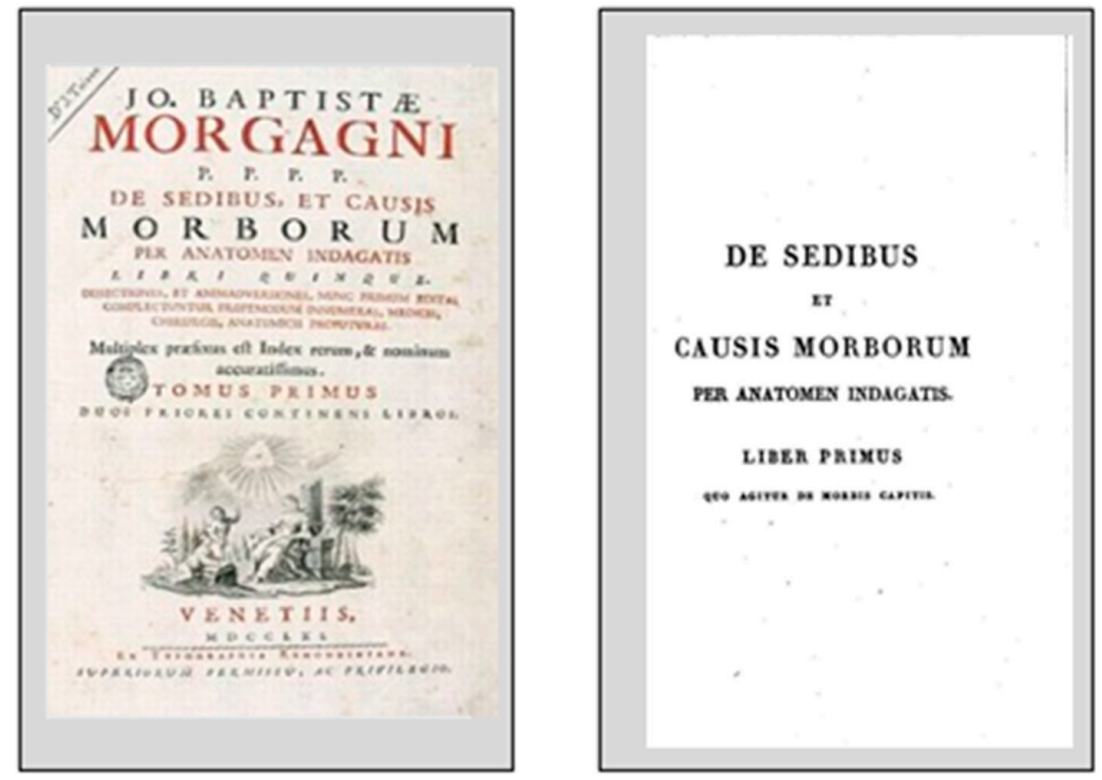

Figure 1. Joannes Baptista Morgagni's ‘De Sedibus et Causis Morborum per Anatomen Indagata'.

In 1765, the Italian medical genius, JB Morgagni, lucidly identified the principal features of what we would now define as metabolic syndrome. He reported on the anatomical basis of "android obesity" and associated such pathological findings with hypertension, hyperuricemia, atherosclerosis and obstructive sleep apnea syndrome, long before the modern recognition of this syndrome [73]. This outstanding achievement descended from Morgagni's mechanistic view of human physiology and pathology. He envisaged health as the result of the well-balanced functioning of the various organs. Conversely, any disease resulted from specific tissue damage, and this is still largely accepted in contemporary medical sciences [73].

However, most contributions belong to the 20th century. During the 1920s, Austrian, Swedish and Spanish authors reported on the association of arterial hypertension, diabetes, obesity, hyperuricemia, and vascular disease [99]. In the same decade, based on insurance data, it was observed that albuminuria/kidney disease, diabetes, cardio-circulatory disease, and high blood pressure clustered in overweight and obese individuals [100]. In 1939, Himsworth identified two different types of diabetes and established an association between insulin resistance and risk of type 2 diabetes [99]. In his seminal studies, conducted for almost 35 years, Vague and his group established a firm association between central distribution of body fat and unfavorable metabolic effects. However, it was not until the early 1980s that, owing to contributions by Kissebah and Bjorntorp, this concept became accepted [76].

The nomenclature of metabolic syndrome has been variable over time, including names such as hypertension-hyperglycaemia-hyperuricaemia syndrome, metabolic trisyndrome, plurimetabolic syndrome, syndrome of affluence, syndrome X, deadly quartet and insulin resistance syndrome [99]. More recent advances in operative definitions of metabolic syndrome are illustrated in Table 2 [69-98]. Studies highlighting the association of metabolic syndrome and NAFLD are shown in Table 3 [6,7,11,101-122]. Collectively, these studies were deemed to be consistent with the notion that NAFLD was "the hepatic manifestation of the Metabolic Syndrome", which agrees with the popular motto that "fatty people have fatty livers". 
Table 2. Principal advances in the history of Metabolic Syndrome [69-98].

\begin{tabular}{|c|c|c|}
\hline Year-Author [Ref] & Findings & Comment \\
\hline $\begin{array}{l}\text { Around } 600 \\
\text { BC-Sushruta [69] }\end{array}$ & $\begin{array}{l}\text { It is believed that ancient Ayurvedic medicine was probably first in envisaging a nexus } \\
\text { linking excess weight and diabetes. Sushruta described diabetes (madhumeha or "honey-like } \\
\text { urine"), as featuring the passage of large amounts of sweet-tasting urine, primarily affecting } \\
\text { obese, sedentary individuals predisposed to developing angina ("hritshoola"). } \\
\text { Sushruta was the first physician recorded to have prescribed exercise to cure diabetes and } \\
\text { obesity. Exercise is described as "moderate in nature or to an intensity that will cause } \\
\text { laboured breathing" }\end{array}$ & $\begin{array}{l}\text { The reasons why features of the MetS were } \\
\text { described by Indo-European as opposed to } \\
\text { North-African clinicians is not completely clear. }\end{array}$ \\
\hline $\begin{array}{l}\text { c. } 460-\text { c. } 370 \\
\text { BC-Hippocrates }[70,71]\end{array}$ & $\begin{array}{l}\text { Hippocrates had clear ideas regarding the fact that obesity was associated with sexual } \\
\text { dysfunction in either sex. Moreover, he had observed cases of sudden deaths among obese } \\
\text { people (Those who are constitutionally very fat are more apt to die quickly than those who are thin.) } \\
\text { and advised lifestytle changes to his patients. However, an aphorism says The more severely } \\
\text { diet is restricted, the sooner will the rebellious patient break the rule, will overeat and later suffer both } \\
\text { for the doctor's and his own mistake. } \\
\text { A more active lifestyle was also among Hippocrates' precepts: Walking is man's best medicine. }\end{array}$ & $\begin{array}{l}\text { It would seem that Hippocrates had already } \\
\text { understood that obesity poses multiple health } \\
\text { risks and that lifestyle changes, i.e., dieting } \\
\text { (without excessive restrictions) and exercising } \\
\text { are useful in contrasting these. }\end{array}$ \\
\hline Avicenna—981 [69] & $\begin{array}{l}\text { The very obese are at risk of a fatal rupture of a blood vessel. They are vulnerable to stroke, } \\
\text { hemiplegia and palpitation. }\end{array}$ & $\begin{array}{l}\text { A lucid analysis of cardiovascular risk } \\
\text { associated with obesity. }\end{array}$ \\
\hline 1765-Morgagni JB [72] & $\begin{array}{l}\text { A 74-year-old lady with severe obesity and an android aspect died owing to stroke. At } \\
\text { autopsy intrabdominal and intramediastinal cavities were filled with a large amount of fat. } \\
\text { A flabby, obese sedentary gentleman engaged in literature studies, and indulgent towards } \\
\text { opulent meals had a short, thick "bull-like" neck". At the age of } 40 \text { he started passing } \\
\text { pink-orange colored bladder stones, with urine. At the age of } 61 \text { he started complaining of } \\
\text { headaches and sleepiness. When he was } 63 \text { he developed peripheral edema, aphasia, right } \\
\text { side hemiplegia and eventually died. Necropsy identified bladder stones; reddish lungs; } \\
\text { enlarged heart and severe calcific atherosclerosis of the carotid and vertebral arteries. }\end{array}$ & $\begin{array}{l}\text { Although laboratory tests and imaging } \\
\text { techniques were not available in the 18th } \\
\text { century, the anatomo-clinical reports written by } \\
\text { JB Morgagni are deemed to be the very first } \\
\text { description of visceral obesity and related } \\
\text { complications in either sex [73]. }\end{array}$ \\
\hline 1924-Joslin [74] & $\begin{array}{l}\text { "Diabetes is } 15 \text { times as common among } \\
\text { adults and } 20 \text { times as common among the fat" }\end{array}$ & $\begin{array}{c}\text { Elliott Joslin was the first US doctor specialized } \\
\text { in diabetes care. }\end{array}$ \\
\hline 1939-Himsworth [74] & $\begin{array}{c}\text { "On the whole the sensitive diabetics tend to be younger and thin and to have a normal blood pressure } \\
\text { and normal arteries, and as a rule their disease is of sudden and severe onset. } \\
\text { The insensitive diabetics, on the other hand, tend to be elderly and obese and to have hypertension and } \\
\text { arteriosclerosis, and in these patients the onset is insidious" }\end{array}$ & $\begin{array}{l}\text { This Author identified two different types of } \\
\text { diabetes, of which "insensitive diabetes" is what } \\
\text { we now call T2D. }\end{array}$ \\
\hline
\end{tabular}


Table 2. Cont

\begin{tabular}{|c|c|c|}
\hline Year-Author [Ref] & Findings & Comment \\
\hline 1947-Vague [75] & $\begin{array}{l}\text { This pioneering paper was published in French at the end of World War II. Vague reports that } \\
\text { relative hyperanabolism, the basis of obesity and sexual differentiation work together to } \\
\text { produce android, gynoid or mixed obesity. }\end{array}$ & $\begin{array}{l}\text { This seminal work by Vague, published in } \\
\text { French, is deemed to probably have suffered } \\
\text { from a limited availability of resources owing to } \\
\text { World War II [76]. However Vague continued } \\
\text { his studies for many years and, in 1956, he } \\
\text { reported on the association of android obesity } \\
\text { with the risk of developing diabetes, } \\
\text { hypertension, gout and atherosclerosis [77]. }\end{array}$ \\
\hline 1967-Avogaro [78] & $\begin{array}{l}\text { A report of } 6 \text { mildly obese patients with stable non-ketonuric diabetes-induced } \\
\text { hyperlipidemia. Treatment with a low-calorie, low- carbohydrate diet, induced weight loss, } \\
\text { was effective in normalizing/markedly decreasing fasting blood glucose and serum } \\
\text { triglyceride values. }\end{array}$ & $\begin{array}{l}\text { A lucid analysis of the close association linking } \\
\text { carbohydrate intake with metabolic } \\
\text { derangements. }\end{array}$ \\
\hline 1969-Feldman [79] & This study shows that central body fat distribution is associated with the development of T2D & $\begin{array}{l}\text { Although confirmative of the findings } \\
\text { previously reported by Vague, this paper failed } \\
\text { to gain scientific awareness. }\end{array}$ \\
\hline 1982-Kissebah [80] & $\begin{array}{l}9 \text { non-obese apparently healthy women and } 25 \text { obese women, were evaluated. } \\
\text { Plasma glucose, insulin levels during oral glucose loading, triglycerides and diabetes were } \\
\text { associated with obesity predominantly affecting the upper body segment. } \\
\text { Upper body obesity was comprised of large adipocytes, while adiposity in the lower body } \\
\text { was formed of normal-sized cells. In both types of obesity, the size of abdominal adipocytes } \\
\text { was significantly associated with postprandial plasma glucose and insulin levels. Thigh } \\
\text { adipocytes were resistant to epinephrine-stimulated lipolysis. }\end{array}$ & $\begin{array}{l}\text { In women, impaired glucose disposal, } \\
\text { hyperinsulinemia and hypertriglyceridemia } \\
\text { occur as a result of the specific morphology and } \\
\text { metabolic attitudes of adipocytes associated } \\
\text { with upper body obesity. }\end{array}$ \\
\hline 1983-Krotkiewski [81] & $\begin{array}{l}\text { This study showed with stepwise multiple regression analyses that, in both women and men, } \\
\text { the complications of obesity were linked to waist/hip circumference. }\end{array}$ & $\begin{array}{l}\text { This is the first of a series of studies conducted } \\
\text { by these authors. A subsequent study published } \\
\text { in } 1984 \text { established the concept that, in middle } \\
\text { aged men, the distribution of fat deposits may } \\
\text { better predict CVD and death than the degree of } \\
\text { adiposity [82]. }\end{array}$ \\
\hline 1987-Fujioka [83] & $\begin{array}{l}\text { The association of intra-abdominal adipose tissue (evaluated with CT scan) and disorders of } \\
\text { glucose and lipid metabolism was evaluated in } 46 \text { obese individuals. } \\
\text { The V/S ratio was significantly correlated with the level of plasma glucose AUC of } 75 \mathrm{~g} \\
\text { OGTT, with triglyceridemia and total cholesterolemia. }\end{array}$ & $\begin{array}{l}\text { The accumulation of intra-abdominal fat } \\
\text { predisposes to impaired glucose tolerance and } \\
\text { dyslipidemia in obese individuals. }\end{array}$ \\
\hline
\end{tabular}


Table 2. Cont

\begin{tabular}{|c|c|c|}
\hline Year-Author [Ref] & Findings & Comment \\
\hline 1988-Reaven [84] & $\begin{array}{l}\text { This lecture lucidly describes the chain of pathophysiological events which occur in most of } \\
\text { the patients with either IGT or T2D and in a quarter of non-obese glucose normo-tolerant } \\
\text { individuals. Hyperinsulinemia may effectively prevent frank decompensation of glucose } \\
\text { homeostasis at the price of developing HTN, hyperglycemia, dyslipidemia, and CAD. }\end{array}$ & $\begin{array}{l}\text { This Banting Lecture raises the possibility that } \\
\text { resistance to insulin-stimulated glucose uptake } \\
\text { and hyperinsulinemia are involved in the } \\
\text { development and progression of T2D, HTN, and } \\
\text { CAD }\end{array}$ \\
\hline 1989-Kaplan [85] & $\begin{array}{l}\text { The evidence that upper-body obesity, which usually occurs as a result of calorie excess in the } \\
\text { presence of androgens, predisposes to hypertension, diabetes, and hypertriglyceridemia even } \\
\text { in the absence of significant overall obesity mediated by hyperinsulinemia. }\end{array}$ & $\begin{array}{l}\text { There is a need to identify and prevent } \\
\text { upper-body obesity. Whenever this fails, } \\
\text { therapies should be provided that would control } \\
\text { the "deadly quartet" without worsening } \\
\text { hyperinsulinemia. }\end{array}$ \\
\hline 1991-Ferrannini [86] & $\begin{array}{c}\text { Among } 2930 \text { subjects from the general population, the prevalence of obesity, T2D, IGT, HTN, } \\
\text { hypertriglyceridemia, and hypercholesterolemia alone, two by two or in association was } \\
\text { evaluated. } \\
\text { The large differences in prevalence between isolated and mixed forms suggest important } \\
\text { overlapping among the six components of the MetS. In their isolated forms, each condition } \\
\text { was characterized by hyperinsulinaemia which is evidence for IR. Fasting and post-glucose } \\
\text { hyperinsulinaemia was associated with higher BMI, WHR, fasting and post-glucose } \\
\text { glycaemia, systolic and diastolic BP, serum triglycerides and total cholesterol levels and } \\
\text { lower HDL-cholesterol concentrations. }\end{array}$ & $\begin{array}{l}\text { IR, glucose intolerance, HTN, body fat mass and } \\
\text { distribution, and serum lipids are a network of } \\
\text { mutually interrelated functions; each and all of } \\
\text { the six disorders increase the risk of CAD. }\end{array}$ \\
\hline $\begin{array}{l}\text { 1999_WHO Alberti and } \\
\text { Zimmet [87] }\end{array}$ & $\begin{array}{l}\text { Proceedings of a meeting held in London in } 1996 \text { under the sponsorship of Bayer, Novo and } \\
\text { The Institute for Diabetes Discovery. This document also incorporated subsequent comments } \\
\text { from the Experts. }\end{array}$ & $\begin{array}{l}\text { This document was first to include insulin } \\
\text { resistance as a diagnostic criterion of the MetS. }\end{array}$ \\
\hline $\begin{array}{l}\text { 1999_Balkau \& Charles } \\
\text { [88] }\end{array}$ & The EGIR proposed that 3 out of 5 clinical criteria were sufficient to define the MetS. & $\begin{array}{l}\text { Diagnostic criteria proposed by EGIR were IR } \\
\text { and } \geq 2 \text { criteria among central obesity, high } \\
\text { triglycerides or low HDL, HTN, and fasting } \\
\text { glucose } \geq 6.1 \mathrm{mmol} / \mathrm{L} \text {. }\end{array}$ \\
\hline 2001-NCEP [89] & $\begin{array}{l}\text { Updated clinical guidelines for cholesterol testing and intensive cholesterol-lowering } \\
\text { treatment in clinical practice. An evidence-based and extensively referenced document } \\
\text { report which provides the scientific foundations for the recommendations contained in the } \\
\text { executive summary. }\end{array}$ & $\begin{array}{l}\text { These guidelines are meant to inform rather } \\
\text { than replace clinical judgment. }\end{array}$ \\
\hline
\end{tabular}


Table 2. Cont.

\begin{tabular}{|c|c|c|}
\hline Year-Author [Ref] & Findings & Comment \\
\hline 2002-Ford [90] & $\begin{array}{c}\text { In this analysis of data on } 8814 \text { adult men and women from the 3rd NHANES (1988-1994). } \\
\text { The age-adjusted prevalence rate of the MetS was } 23.7 \% \text {, similar in men and women but } \\
\text { varied based on ethnicity. Using } 2000 \text { census data, about } 47 \text { million US residents have the } \\
\text { MetS. }\end{array}$ & $\begin{array}{l}\text { Based on } 2000 \text { census data, about } 47 \text { million US } \\
\text { residents were estimated to have the MetS } \\
\text { carrying major implications for health care. }\end{array}$ \\
\hline 2004-Grundy [91] & $\begin{array}{l}\text { The scientific foundations underlying the definition of MetS was considered from several } \\
\text { perspectives spanning from metabolic components and pathogenesis to criteria for diagnosis, } \\
\text { clinical outcomes and therapeutic interventions. }\end{array}$ & $\begin{array}{l}\text { The primary outcomes of MetS are CVD and } \\
\text { T2D. T2D will further contribute to increasing } \\
\text { CVD risk. } \\
\text { ATP III criteria are practical in identifying } \\
\text { patients at increased risk for CVD. } \\
\text { Irrespective of the diagnostic criteria used, } \\
\text { lifestyle changes, notably including weight loss, } \\
\text { represent a first-line therapeutic approach for } \\
\text { MetS. }\end{array}$ \\
\hline 2005—Grundy [92] & $\begin{array}{l}\text { MetS defines a constellation of endogenous risk factors which predispose to ASCVD and } \\
\text { T2D. MetS is multi-factorial and exhibits major inter-individual, inter-racial and inter-ethnic } \\
\text { variability. }\end{array}$ & $\begin{array}{l}\text { In the USA, the MetS is strongly associated with } \\
\text { abdominal obesity. Lifestyle changes are the } \\
\text { first-line interventions and drug therapies for } \\
\text { individual risk factors may be indicated } \\
\text { whenever lifestyle changes fail. }\end{array}$ \\
\hline 2005-Kahn [93] & $\begin{array}{l}\text { Concerns are raised regarding diagnostic criteria; rationale for using thresholds in biological } \\
\text { parameters; the importance of including diabetes in the definition; uncertainty as to IR as the } \\
\text { unifying etiology; absence of clear grounds for including/excluding other CVD risk factors; } \\
\text { variable value in assessing the risk of CVD; failure of the MetS to identify CVD risk more } \\
\text { accurately than its individual components; management of the MetS overlapping with that of } \\
\text { each of its constitutive components; the added value of diagnosing the syndrome is uncertain. }\end{array}$ & $\begin{array}{l}\text { The principal value in identifying the MetS is } \\
\text { based on the notion that the individual } \\
\text { components of the MetS tend to cluster in the } \\
\text { same individuals and each of these often } \\
\text { foreruns the incidence of additional components } \\
\text { over time. Along with the risk of progressing to } \\
\text { target organ failure (e.g., cirrhosis) and of the } \\
\text { development of some cancer types (e.g., HCC) } \\
\text { makes MetS a relevant diagnosis for practicing } \\
\text { clinicians and a global major public health } \\
\text { problem [94] }\end{array}$ \\
\hline
\end{tabular}


Table 2. Cont.

\begin{tabular}{|c|c|c|}
\hline Year-Author [Ref] & Findings & Comment \\
\hline 2005-Reaven [95] & $\begin{array}{l}\text { While the concept of IR provides a pathophysiologic framework } \\
\text { bringing together a number of seemingly unrelated biological phenomena, the MetS is a } \\
\text { pragmatic approach aimed at making a diagnosis to initiate lifestyle changes and decreasing } \\
\text { CVD risk. }\end{array}$ & $\begin{array}{l}\text { The diagnosis of the MetS will not promote our } \\
\text { pathophysiologic understanding or clinical } \\
\text { utility: deciding that individuals do not have the } \\
\text { MetS owing to their failure to satisfy } 3 \text { out of } 5 \\
\text { arbitrary criteria may withhold important } \\
\text { therapeutic decisions. }\end{array}$ \\
\hline 2009_Alberti [96] & $\begin{array}{l}\text { The MetS defines HTN, atherogenic dyslipidemia, hyperglycemia, and central obesity } \\
\text { - which are risk factors for CVD and T2D - and tend to cluster more often than due to chance } \\
\text { alone. Various diagnostic criteria have been proposed by different organizations over time } \\
\text { which chiefly differ regarding the measurement of central obesity. }\end{array}$ & $\begin{array}{c}\text { This statement tries to unify existing criteria. } \\
\text { It was concluded that there should not be an } \\
\text { obligatory component, but that waist } \\
\text { measurement would be a useful screening tool. } \\
3 \text { out of } 5 \text { abnormal findings would qualify an } \\
\text { individual for the MetS. } \\
\text { National/regional cut-off values for WC can be } \\
\text { used. }\end{array}$ \\
\hline
\end{tabular}

The notion of MetS focuses on complex

2010-Simmons [97] Conclusions of a WHO Expert consultation evaluating the utility of the concept itself of MetS 'as related to epidemiology, physiopathology, clinical aspects and public health.
Therefe, it is useful as an educational concept while its clinical value as a diagnostic or management tool is quite limited. Perspectives for future research are also discussed

The definition of VAS is well taken in as much as it highlights the key anatomical basis underlying metabolic derangements which had astutely been identified by Morgagni.

ASCVD—atherosclerotic cardiovascular disease; BP—blood pressure; CAD—coronary artery disease; CVD—cardiovascular disease; EGIR—european group for the study of insulin resistance; HCC—-hepatocellular carcinoma; HTN—arterial hypertension; MetS—-metabolic syndrome; NCEP/ATP III—National Cholesterol Education Program/Adult Treatment Panel III; NHANES - National Health and Nutrition Examination Survey; T2D—type 2 diabetes; VAS—visceral adiposity syndrome; V/S ratio—visceral fat to subcutaneous fat ratio; WC — waist circumference; WHO-World Health Organization; WHR - waist to hip ratio. 
Table 3. Principal advances in the history of the association of NAFLD with the Metabolic Syndrome.

\begin{tabular}{|c|c|c|c|}
\hline Year-Author [Ref] & Method & Findings & Comment \\
\hline 1935-Zelman [101] & $\begin{array}{c}\text { Review of experimental pathology and clinical } \\
\text { science. }\end{array}$ & $\begin{array}{l}\text { "Although the increased incidence in human obesity of } \\
\text { gallbladder disease and diabetes mellitus }{ }^{4} \text { has long been } \\
\text { known, and although these conditions may lead } \\
\text { independently to liver disease, there does not appear to be } \\
\text { in the literature a consideration of the existence of liver } \\
\text { damage in obesity per se. The majority of obese persons } \\
\text { show a significant decrease in carbohydrate tolerance, and } \\
\text { this impairment has been related to the duration rather } \\
\text { than to the degree of obesity. Similar decreases in } \\
\text { carbohydrate tolerance are observed in the experimental } \\
\text { obesity of hypothalamic injury and in hereditarily } \\
\text { obese mice." }\end{array}$ & $\begin{array}{l}\text { A clear allusion to what we would now } \\
\text { call "MAFLD". } \\
\text { This study also reports on the risk of } \\
\text { developing a specific form of progressive } \\
\text { NASH secondary to injuries of the } \\
\text { hypothalamic-hypophyseal axis. }\end{array}$ \\
\hline $\begin{array}{l}\text { 1970-Beringer and } \\
\text { Thaler [102] }\end{array}$ & 465 liver biopsies performed in diabetics. & $\begin{array}{l}\text { Being overweight, rather than diabetes duration or } \\
\text { metabolic control, was associated with the severity } \\
\text { of hepatic steatosis. } \\
\text { Among various forms of treatment, only treatment } \\
\text { with insulin was significantly associated with the } \\
\text { degree of steatosis. }\end{array}$ & $\begin{array}{l}\text { Most of these patients had } \\
\text { maturity-onset diabetes associated with } \\
\text { obesity. }\end{array}$ \\
\hline 1977-Haller [103] & $\begin{array}{l}\text { The Dresden study addressed the most } \\
\text { important CVR factors. }\end{array}$ & $\begin{array}{c}\text { Obesity } 8.2 \% \text {, hyperlipoproteinemia } 7.4 \% \text {, } \\
\text { hyperuricemia } 3.8 \% \text {, T2D } 2.0 \% \text {, hypertension } 17.2 \% \\
\text { and smoking } 30.3 \% \text { were the most common CVR } \\
\text { factors. }\end{array}$ & $\begin{array}{l}\text { "MetS" is defined as the concurrence of } \\
\text { obesity, T2D, hyperlipoproteinemia, } \\
\text { hyperuricemia, and hepatic steatosis. } \\
\text { Haller recognizes this MetS as being } \\
\text { associated with increased risk of } \\
\text { artheriosclerosis owing to increased } \\
\text { blood viscosity and procoagulant state. }\end{array}$ \\
\hline 1979—Itoh [104] & A report of five cases. & $\begin{array}{c}\text { Five nonalcoholic diabetic women over } 50 \text { years of } \\
\text { age who had obesity and hyperglycemia, were } \\
\text { found to have clinically and histologically proven } \\
\text { micronodular cirrhosis. }\end{array}$ & $\begin{array}{l}\text { The histological findings differed from } \\
\text { cirrhosis following hepatitis and } \\
\text { developed owing to centrilobular } \\
\text { necrosis. }\end{array}$ \\
\hline
\end{tabular}


Table 3. Cont

\begin{tabular}{|c|c|c|c|}
\hline Year-Author [Ref] & Method & Findings & Comment \\
\hline $\begin{array}{l}\text { 1979_Adler and } \\
\text { Schaffner [6] }\end{array}$ & $\begin{array}{l}\text { Criteria for inclusion: obese subjects ( } \geq 50 \% \\
\text { overweight for height based on Insurance } \\
\text { Company standards) referred owing to either } \\
\text { hepatomegaly or abnormal liver tests. Criteria } \\
\text { for exclusion: excessive alcohol consumption, } \\
\text { drug abuse, acute or chronic liver disease; } \\
\text { HBsAg; AMA; biopsy-proven chronic hepatitis. } \\
\text { abnormal imaging findings regarding } \\
\text { gallbladder or bile duct; impaired renal function; } \\
\text { abnormal results of routine blood counts; } \\
\text { disease of the digestive tract; infection or cardiac } \\
\text { decompensation. Based on liver histology, } \\
\text { patients were classified into one of the following } \\
\text { categories: Group I. Fatty liver; Group II. Fatty } \\
\text { hepatitis; Group III. Fatty fibrosis and Group IV. } \\
\text { Fatty cirrhosis. }\end{array}$ & 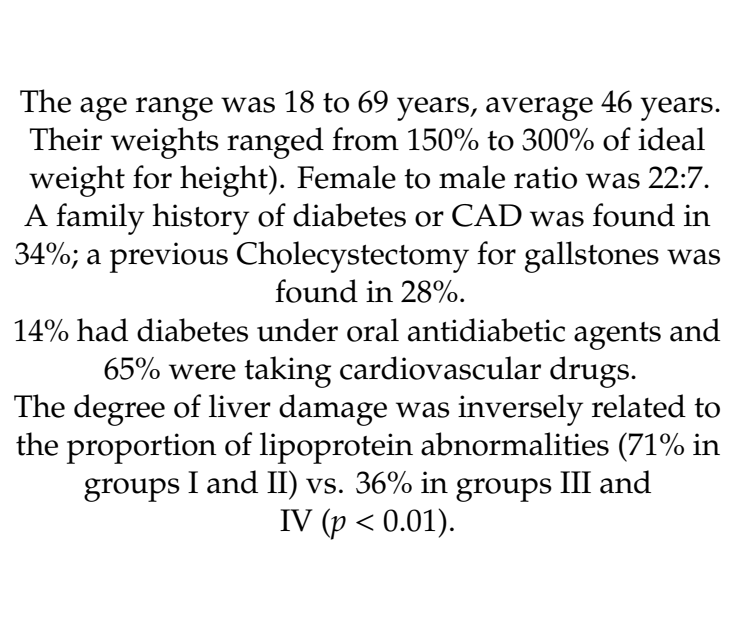 & $\begin{array}{l}\text { In obese individuals presenting with } \\
\text { either clinical or laboratory evidence of } \\
\text { liver disease, all the histological } \\
\text { spectrum of alcoholic hepatitis can be } \\
\text { observed. } \\
\text { Prevalence of the female sex, a high } \\
\text { incidence of gallstones, HTN, T2D and } \\
\text { hyperlipo-proteinemia (predominantly } \\
\text { type IV of Frederickson's classification) } \\
\text { were the most prominent clinical features } \\
\text { found in this series of obese patients. }\end{array}$ \\
\hline 1980_Ludwig [7] & Findings in 20 patients with NASH are reported. & $\begin{array}{l}\text { Liver biopsy findings exhibited striking fatty } \\
\text { changes with lobular hepatitis, focal necroses with } \\
\text { mixed inflammatory infiltrates, Mallory bodies and } \\
\text { fibrosis. Three had cirrhosis. } \\
\text { The disease was more common in obese women } \\
\text { most of whom also had T2D and gallstones. }\end{array}$ & $\begin{array}{l}\text { This seminal study was first in } \\
\text { associating the novel name NASH with } \\
\text { its clinico-pathological correlates. }\end{array}$ \\
\hline 1989-Lee [105] & $\begin{array}{c}\text { A retrospective analysis yielded } 49 \text { cases of } \\
\text { NASH out of } 543 \text { liver biopsies diagnosed as } \\
\text { alcoholic hepatitis. Follow-up information after } \\
\text { an average duration of } 3.8 \text { years was available } \\
\text { for } 39 \text { patients }\end{array}$ & $\begin{array}{l}\text { NASH tends to be a mild condition with the } \\
\text { potential to progress to cirrhosis in some patients } \\
\text { owing to unknown mechanisms. }\end{array}$ & $\begin{array}{l}\text { In this pioneering study devoted to } \\
\text { identifying the natural history of disease } \\
\text { female sex, obesity and diabetes were } \\
\text { prominent features of disease. }\end{array}$ \\
\hline 1990_Powell [106] & $\begin{array}{c}\text { Forty-two NASH patients were followed for a } \\
\text { median of } 4.5 \text { yrs (range = } 1.5 \text { to } 21.5 \text { yrs). All } \\
\text { were obese except for two who had } \\
\text { lipodystrophy. } 35 / 42 \text { were women, } \\
\text { 26/32 had hyperlipidemia and } 15 / 32 \\
\text { hyperglycemia. }\end{array}$ & $\begin{array}{l}\text { NASH is a low-grade and slowly progressing } \\
\text { chronic hepatitis resembling alcoholic liver disease } \\
\text { which may, however, ultimately result in cirrhosis. }\end{array}$ & $\begin{array}{l}\text { Decompensated diabetes and rapid } \\
\text { weight loss preceded the onset of NASH } \\
\text { Severity of obesity, hyperlipidemia or } \\
\text { hyperglycemia was not associated with } \\
\text { the histological type/severity of disease. }\end{array}$ \\
\hline
\end{tabular}


Table 3. Cont

\begin{tabular}{|c|c|c|c|}
\hline Year-Author [Ref] & Method & Findings & Comment \\
\hline 1994-Bacon [107] & A series of 33 patients with NASH is analyzed. & $\begin{array}{c}\text { All patients were HCV-Ab-negative. } 58 \% \text { were men, } \\
\text { and } 39 \% \text { had pathologically increased liver fibrosis, } \\
5 \text { of whom had micronodular cirrhosis. } \\
\text { NASH was also found in men without any obvious } \\
\text { metabolic risk factors. However, those } 13 \text { cases with } \\
\text { more advanced fibrosing disease, were } \\
\text { predominantly obese women, with either T2D or } \\
\text { IFG and hyperlipidemia. No patient had } \\
\text { hemochromatosis although } 58 \% \text { displayed abnormal } \\
\text { values of transferrin saturation and ferritin. }\end{array}$ & $\begin{array}{l}\text { The NASH spectrum should be } \\
\text { expanded as compared to Ludwig's } \\
\text { initial description [7]. }\end{array}$ \\
\hline 1995-Lonardo [11] & $\begin{array}{c}\text { A series of } 339 \text { patients submitted to } \\
\text { ultrasonography scanning owing to clinical } \\
\text { indications is evaluated. A minority of } \\
\text { individuals were either HCV-Ab positive and all } \\
\text { drank < } 20 \text { g alcohol daily, } 21.5 \% \text { had a "bright } \\
\text { liver". }\end{array}$ & $\begin{array}{l}\text { Among those with a bright liver echopattern there } \\
\text { was a prevalence of men. Overweight, arterial } \\
\text { hypertension, gallstones, (previously undiagnosed) } \\
\text { impaired glucose disposal, raised apoB and Lp (a) } \\
\text { serum levels and clinical manifest atherosclerotic } \\
\text { vascular disease were common. }\end{array}$ & $\begin{array}{l}\text { A bright liver echopattern is often } \\
\text { associated with extrahepatic multisystem } \\
\text { involvement and could be a clue to } \\
\text { identifying metabolic and cardiovascular } \\
\text { diseases. }\end{array}$ \\
\hline $\begin{array}{l}\text { 1999-Cortez-Pinto } \\
\text { [108] }\end{array}$ & $\begin{array}{l}\text { Body composition (with bioimpedance } \\
\text { spectroscopy) and energy expenditure (with } \\
\text { indirect calorimetry) were assessed in } 10 \\
\text { patients with biopsy-proven steatosis, } 20 \text { with } \\
\text { NASH and } 8 \text { healthy controls. }\end{array}$ & $\begin{array}{l}\text { The prevalence of features of the Mets in NAFLD } \\
\text { was as follows: obesity and dyslipidaemia } 80 \% \text { each; } \\
\text { HTN 50\%; T2D 33\%; impaired glucose metabolism } \\
69 \% \text {. Hyperinsulinemia and hyperleptinemia were } \\
\text { common. Insulin and leptin were mutually } \\
\text { associated and correlated with BMI, fat mass and } \\
\text { body fat percentage. }\end{array}$ & $\begin{array}{c}\text { NAFLD is strongly associated with } \\
\text { features of the MetS. Such an association } \\
\text { is mediated by concurrent IR and leptin } \\
\text { resistance. }\end{array}$ \\
\hline 1999_Lonardo [109] & $\begin{array}{l}\text { A Medline research of the literature covering the } \\
\text { years 1990-1998 and cross references was } \\
\text { conducted. }\end{array}$ & $\begin{array}{l}\text { Fatty liver typically affects middle aged men with } \\
\text { features of the MetS such as obesity, altered glucose } \\
\text { disposal, hyperlipidemia and HTN }\end{array}$ & $\begin{array}{l}\text { The similarities of fatty liver with the } \\
\text { MetS span epidemiology, anthropometry, } \\
\text { metabolism, clinical features and } \\
\text { experimental models. }\end{array}$ \\
\hline
\end{tabular}


Table 3. Cont

\begin{tabular}{|c|c|c|c|}
\hline Year-Author [Ref] & Method & Findings & Comment \\
\hline $\begin{array}{c}\text { 1999-Marchesini } \\
\text { [110] }\end{array}$ & $\begin{array}{l}\text { Anthropometric and metabolic variables were } \\
\text { evaluated in } 46 \text { patients with normo-glucose } \\
\text { tolerant NAFLD [defined by chronically raised } \\
\text { serum transaminases, compatible ultrasound } \\
\text { scanning and exclusion of competing etiologies } \\
\text { of liver disease]; and compared to } 92 \text { age- and } \\
\text { sex- matched healthy controls. }\end{array}$ & $\begin{array}{c}\text { NAFLD cases exhibited (fasting and } \\
\text { glucose-induced) hyperinsulinemia, IR, } \\
\text { asymptomatic postload hypoglycemia, and } \\
\text { hypertriglyceridemia. } \\
\text { The independent predictors of NAFLD were IR, } \\
\text { fasting TG serum concentrations, 180-min blood } \\
\text { serum glucose level and average insulin } \\
\text { concentration following oral glucose. } \\
\text { The exclusion of overweight and obese subjects did } \\
\text { not alter these findings. }\end{array}$ & $\begin{array}{l}\text { Normo-glycemic NAFLD, obesity and } \\
\text { T2D belong to the same spectrum of } \\
\text { disease which is associated with } \\
\text { hyperinsulinemia, IR and } \\
\text { hypertriglyceridemia. } \\
\text { Either life-style changes or } \\
\text { insulin-sensitizing agents may break the } \\
\text { association of hyperinsulinemia, IR, } \\
\text { hyperTG, thereby halting the } \\
\text { progression of liver steatosis. }\end{array}$ \\
\hline 1999-Marceau [111] & $\begin{array}{l}551 \text { (112 men) morbidly obese individuals } \\
\text { submitted to bariatric surgery were evaluated. }\end{array}$ & $\begin{array}{l}\text { Steatosis was found in } 86 \% \text {, fibrosis in } 74 \% \text {, mild } \\
\text { inflammation/steatohepatitis in } 24 \% \text {, and } \\
\text { unexpected cirrhosis in } 2 \text {. The risk of steatosis was } \\
2.6 \text { times greater in men than in women. Per each } \\
\text { addition of } 1 \text { of the } 4 \text { components of the MetS, the } \\
\text { risk of steatosis increased exponentially. Fibrosis } \\
\text { was correlated with steatosis and the presence of } \\
\text { either diabetes or IGT carried a 7-fold increased risk } \\
\text { of fibrosis. } \\
\text { T2D, steatosis, and age were all significant } \\
\text { indicators of cirrhosis. }\end{array}$ & $\begin{array}{l}\text { The MetS is strongly associated with } \\
\text { steatosis, fibrosis, and cirrhosis via IGT. }\end{array}$ \\
\hline 2002-Lonardo [112] & $\begin{array}{l}60 \text { patients with NAFLD and } 60 \text { age and } \\
\text { sex-matched controls were analyzed. }\end{array}$ & $\begin{array}{l}\text { Patients exhibited hypertriglyceridemia, } \\
\text { hyperuricemia, hyperisulinemia and obesity more } \\
\text { often than controls. No iron storage was found } \\
\text { among those who underwent liver biopsy. }\end{array}$ & $\begin{array}{l}\text { Only fasting insulin and serum uric acid } \\
\text { rather than indices of iron metabolism } \\
\text { were independent predictors of NAFLD }\end{array}$ \\
\hline 2004-Donati [113] & $\begin{array}{l}55 \text { patients who had arterial hypertension but } \\
\text { were non-obese, non-diabetic, not drinkers of } \\
\text { large amounts of alcohol and had normal liver } \\
\text { enzymes were compared to } 55 \text { age- and sex- } \\
\text { matched healthy controls. }\end{array}$ & $\begin{array}{l}\text { Among patients with HTN, NAFLD was more } \\
\text { prevalent and these patients were also more insulin } \\
\text { resistant and had higher BMIs than controls. At LRA } \\
\text { IR (OR 1.66, 95\% CI 1.03-2.52) and BMI (OR 1.22, } \\
95 \% \text { CI 1.00-1.49) were independently associated } \\
\text { with NAFLD; moreover, IR was predicted by ALT ( } p \\
\quad=0.002), \text { HTN }(p=0.029) \text {, and BMI }(p=0.048) .\end{array}$ & $\begin{array}{l}\text { IR and higher body weight account for } \\
\text { the higher prevalence of NAFLD among } \\
\text { non-obese hypertensive patients with } \\
\text { normal liver enzymes. }\end{array}$ \\
\hline
\end{tabular}


Table 3. Cont

\begin{tabular}{|c|c|c|c|}
\hline Year-Author [Ref] & Method & Findings & Comment \\
\hline 2005—Suzuki [114] & $\begin{array}{l}529 \text { individuals who drank }<14 \mathrm{~g} \text { alcohol/wk } \\
\text { and were HBV and HCV negative were selected } \\
\text { and a sub-cohort of } 287 \text { IR-free related features } \\
\text { subjects were identified. } \\
\text { Otherwise unexplained raised transaminases } \\
\text { were used as a surrogate index for NAFLD. } \\
\text { High transaminases, together with weight gain } \\
\text { of }>2 \mathrm{~kg} \text { and IR-related features in the } \\
\text { sub-cohort were sought for up to } 5 \text { yrs. }\end{array}$ & $\begin{array}{l}\text { Weight gain preceded low LDL cholesterol, } \\
\text { hypertriglyceridemia, hypertransaminasemia, HTN, } \\
\text { and glucose intolerance }\end{array}$ & $\begin{array}{l}\text { This study clearly identifies } \\
\text { chronological ordering of the individual } \\
\text { features of the MetS in the development } \\
\text { of surrogate indices of NAFLD. }\end{array}$ \\
\hline 2007-Kotronen [115] & $\begin{array}{l}\text { Features of the MetS, other features of IR (serum } \\
\text { insulin, C-peptide), visceral and sc fat (with } \\
\text { MRI), LFC (with MRS) and transaminases were } \\
\text { evaluated in } 271 \text { non-diabetic subjects. }\end{array}$ & $\begin{array}{l}\text { LFC was } 4 \text {-fold higher in subjects with than without } \\
\text { the MetS independent of age, sex, and BMI. All } \\
\text { features of the MetS were correlated with LFC. LFC } \\
\text { was significantly correlated with transaminases, } \\
\text { fasting serum insulin and C-peptide. }\end{array}$ & $\begin{array}{c}\text { Excess of LFC is associated with the } \\
\text { development of the MetS irrespective of } \\
\text { BMI. }\end{array}$ \\
\hline $\begin{array}{l}\text { 2007-Chitturi and } \\
\text { Farrell [116] }\end{array}$ & $\begin{array}{l}\text { Editorial commenting on two studies published } \\
\text { in the same issue of the journal. }\end{array}$ & $\begin{array}{l}\text { Studies indicating that NAFLD is a pre-diabetic } \\
\text { condition are reviewed. Data useful to answering } \\
\text { the question as to whether liver usltrasonography } \\
\text { can be used to identify patients at risk for metabolic } \\
\text { disease are critically evaluated. }\end{array}$ & $\begin{array}{l}\text { The Authors propose that LFC may } \\
\text { become a "barometer of metabolic } \\
\text { health". } \\
\text { This brilliantly metaphoric definition still } \\
\text { retains all its diagnostic and therapeutic } \\
\text { utility. }\end{array}$ \\
\hline 2008-Musso [117] & $\begin{array}{l}197 \text { unselected non-obese non-diabetic subjects } \\
\text { were evaluated cross-sectionally. } \\
\text { HOMA-IR > 2, oxidative stress (nitrotyrosine), } \\
\text { soluble adhesion molecules (ICAM-1, VACM-1 } \\
\text { and E-selectin) and circulating adipokines } \\
\text { (TNF- } \alpha \text {, leptin, adiponectin and resistin) were } \\
\text { correlated to ATP III criteria for the diagnosis of } \\
\text { the MetS and to NAFLD }\end{array}$ & $\begin{array}{l}\text { IR was more accurately predicted by NAFLD than } \\
\text { ATP III criteria. Accuracy in diagnosing IR was } \\
\text { improved by adding NAFLD to ATP III criteria. } \\
\text { Moreover, at LRA, NAFLD was an independent } \\
\text { predictor of HOMA-IR, nitrotyrosine, and soluble } \\
\text { adhesion molecules at LRA; the presence of NAFLD } \\
\text { entailed more severe oxidative stress and } \\
\text { endothelial dysfunction, independent of } \\
\text { MetS-related confounding factors in subjects with } \\
\text { IR. }\end{array}$ & $\begin{array}{l}\text { In non-obese non-diabetic subjects } \\
\text { NAFLD is more closely associated with } \\
\text { IR, oxidative stress and endothelial } \\
\text { dysfunction than MetS identified with } \\
\text { ATP III criteria.Therefore, in this patient } \\
\text { population, NAFLD may help in } \\
\text { identifying subjects at increased } \\
\text { cardiometabolic risk. }\end{array}$ \\
\hline
\end{tabular}


Table 3. Cont

\begin{tabular}{|c|c|c|c|}
\hline Year-Author [Ref] & Method & Findings & Comment \\
\hline 2010-Vanni [118] & Narrative review & $\begin{array}{l}\text { Emphasis is placed on data suggesting that } \\
\text { hyperinsulinemia, rather than causing, probably } \\
\text { results from pre-existing NAFLD. }\end{array}$ & $\begin{array}{l}\text { One of the first published papers } \\
\text { focusing on the mutual and } \\
\text { bi-directional realtionship linking } \\
\text { NAFLD with the MetS. }\end{array}$ \\
\hline $\begin{array}{c}\text { 2012- }- \text { Hamaguchi } \\
\text { [119] }\end{array}$ & $\begin{array}{l}\text { Cross-sectional survey of } 11,714 \text { apparently } \\
\text { healthy Japanese adult men and women } \\
\text { submitted to a medical health checkup. } \\
\text { NAFLD was identified with ultrasonography } \\
\text { after excluding competing causes of liver } \\
\text { disease. Revised criteria of the NCEPT III were } \\
\text { used to identify MetS. }\end{array}$ & $\begin{array}{l}\text { Although NAFLD is deemed to be the hepatic } \\
\text { manifestation of MetS, the prevalence of MetS in } \\
\text { NAFLD was low in either sex. } \\
\text { When participants were defined as "positive at } \\
\text { screening for NAFLD", those who satisfied at least } \\
\text { one criterion of MetS, had indeed NAFLD with a } \\
\text { good sensitivity ( } 84.8 \% \text { in men and } 86.6 \% \text { in } \\
\text { women). }\end{array}$ & $\begin{array}{l}\text { In epidemiological studies NAFLD can } \\
\text { effectively be identified by modified } \\
\text { criteria of MetS. }\end{array}$ \\
\hline 2015-Zhang [120] & $\begin{array}{l}\text { Based on a large-scale health check-up in a } \\
\text { Chinese population, two bidirectional } \\
\text { longitudinal subcohorts were identified and } \\
\text { followed from } 2005 \text { to } 2011 \text { : Subcohort A [i.e., } \\
\text { from NAFLD to MetS, } n=8426 \text { included those } \\
\text { participants (with or without NAFLD at } \\
\text { baseline) to follow-up the incidence of MetS], } \\
\text { and Subcohort B [i.e., from MetS to NAFLD, } n= \\
\text { 16,110 included those participants (with or } \\
\text { without MetS at baseline) to follow-up the } \\
\text { incidence of NAFLD].Generalized estimating } \\
\text { equation analyses were conducted to assess the } \\
\text { role of NAFLD as a potential causal factor for } \\
\text { MetS and of MetS as a risk factor for incident } \\
\text { NAFLD. } \\
\text { A BN with } 5 \text { simplification strategies was used } \\
\text { in order to infer reciprocal causality. }\end{array}$ & $\begin{array}{l}\text { NAFLD was a potential causal factor for MetS and } \\
\text { MetS was also a factor for NAFLD ( } 2.55,2.23 \text { to } 2.92) \text {. } \\
\text { The total effect of NAFLD on MetS was } 2.49 \% \text {, while } \\
\text { it was } 19.92 \% \text { for MetS on NAFLD. } \\
\text { The total impact of NAFLD on MetS components } \\
\text { was different, with dyslipidemia having the greatest } \\
\text { effect, followed by obesity, diabetes and HTN. } \\
\text { As for the effect of MetS components on NAFLD, } \\
\text { obesity had the greatest effect, followed by T2D, } \\
\text { dyslipidemia and HTN. } \\
\text { The most important causal pathway from NAFLD } \\
\text { to MetS was that NAFLD led to elevated GGT, then } \\
\text { to MetS components, while the dominant causal } \\
\text { pathway from MetS to NAFLD began with } \\
\text { dyslipidaemia. }\end{array}$ & $\begin{array}{l}\text { A reciprocal causality links NAFLD and } \\
\text { MetS. } \\
\text { The impact of MetS on NAFLD is } \\
\text { significantly greater than that of NAFLD } \\
\text { on MetS. }\end{array}$ \\
\hline
\end{tabular}


Table 3. Cont

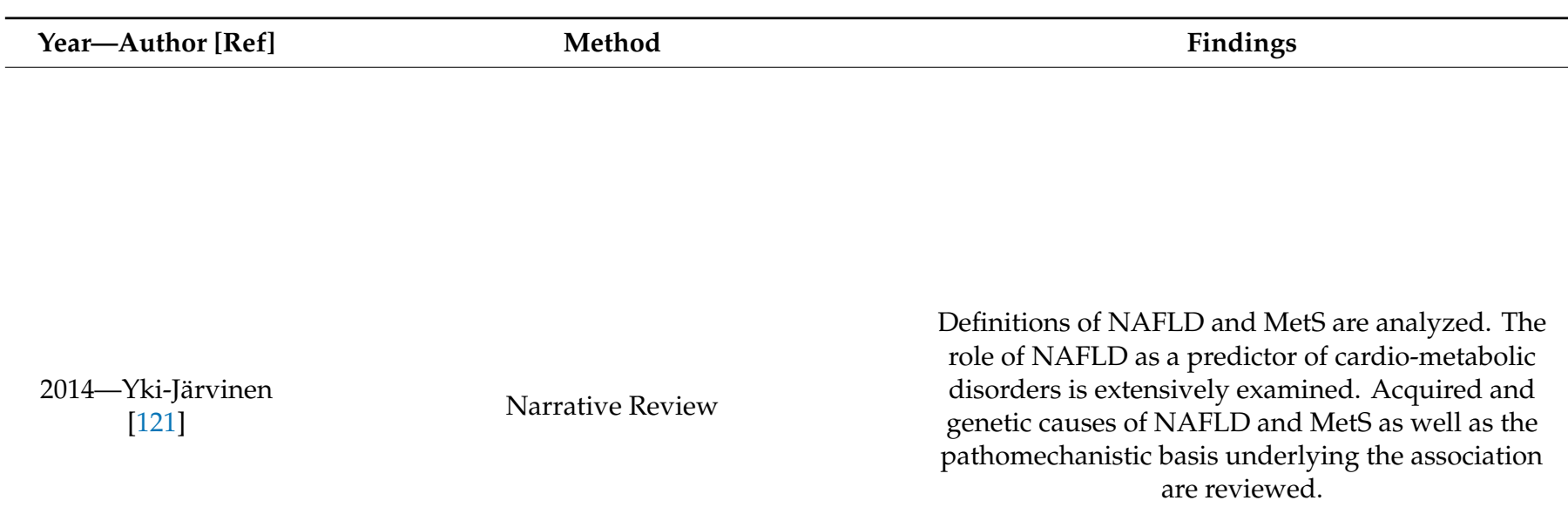

are reviewed.

NAFLD not associated with PNPLA3

polymorphisms is closely reminiscent of

MetS in terms of etiologies and outcomes.

In these patients, LFC is an accurate

barometer of metabolic health.

Groups of individuals at a high risk for

NAFLD include otherwise unexplained

deep venous thromboembolism and

gallstone disease. NAFLD predicts T2D

better than MetS. Therefore, the

diagnosis of NAFLD must invariably prompt the search for the MetS and its individual components. Conversely, the diagnosis of NASH should be pursued among all patients with the MetS.

Lifestyle changes e.g., dietary restrictions

(particularly of simple sugars) and

increased physical activity must be

proposed to both those with NASH and those with the MetS.

Two analyses were conducted. Baseline liver fat (per each SD increase) was associated with increased odds of incident hypertension and T2D. In parallel, compared to individuals free of these conditions, subjects who at the baseline had HTN,

2017-Ma [122]

Prospective study of 1051 participants (mean age $45 \pm 6$ years, $46 \%$ women) followed for approximately 6 yrs. hypertriglyceridemia, IFG, impaired fasting glucose

or T2D had a higher risk of developing incident FL

In both analyses, findings persisted following

further adjustments for measures of adiposity.

This study supports a bi-directional relationship associating FL and CVD risk factors in the 3rd generation cohort of the Framingham Heart Study.

ALT—alanine transaminase; AMA—anti-mitochondrial antibody; AST—aspartate aminotransferase; ATP III—adult treatment panel III; BMI—body mass index; BN—bayesian network; CVR—cardiovascular risk; FL—fatty liver; HBsAg-Hepatitis B surface Antigen; HOMA—homeostasis model assessment; HBV-hepatitis B virus; HCV—hepatitis C virus; HTN—arterial hypertension; ICAM - intracellular adhesion molecule-1; IFG—impaired fasting glucose; IR—insulin resistance; LFC—liver fat content; LRA—logistic regression analysis; MetS-metabolic syndrome; MRI—magnetic resonance imaging; MRS—proton magnetic resonance spectroscopy; NASH—nonalcoholic steatohepatitis; NCEPT—national cholesterol education program adult treatment panel; SC—-subcutaneous; SD—-standard deviation; TG—-triglycerides; T2D-type 2 diabetes; VACM-1 vascular cell adhesion molecule-1. 


\subsection{From NAFLD to the Metabolic Syndrome}

A more recent line of research, however, has shown that the association of NAFLD with metabolic syndrome is mutual and bi-directional. For example, in the early 2000s, it became clear that surrogate indices of hepatic dysfunction predicted incident T2D and metabolic syndrome [123,124]. Bringing these epidemiological data further, it was possible to conduct theoretical as well as meta-analytic studies, showing that NAFLD was indeed a potential precursor of T2D and metabolic syndrome and that the stage of fibrosis was a strong determinant of such a risk $[94,125,126]$.

\subsection{NAFLD and Cardiovascular Risk}

The liver was deemed to harbor life and soul in ancient Middle Eastern cultures, thus assuming a significance similar to that which the heart holds in our contemporary Western society [127,128]. On this historical background, a strong link between NAFLD and cardio-metabolic risk has recently been identified $[129,130]$.

In 1995, Lonardo et al. hypothesized that NAFLD could be a clue that is useful in detecting cardiovascular disease [11]. In 2004 and 2005, Targher et al. were first to report that NAFLD was significantly associated with early carotid atherosclerosis in healthy men, and an increased risk of cardiovascular disease in patients with T2D, independent of classical risk factors, and that the occurrence of metabolic syndrome could account for this, to a partial extent [131,132]. Moreover, these authors also identified the stage of liver fibrosis as an independent predictor of carotid intima-media thickness, after the adjustment for potentially confounding factors such as metabolic syndrome [133]. Since 2005, several studies have confirmed that NAFLD is strongly associated not only with subclinical atherosclerosis [134], but also with major cardiovascular events. In 2016, Targher et al., by meta-analyzing 16 unique, observational studies, enrolling a total of 34,043 adult individuals (36.3\% had NAFLD), and evaluating nearly 2600 CVD events ( $>70 \%$ of which were CVD deaths) followed-up over a median period of 6.9 years, found that NAFLD patients, compared to controls without NAFLD, exhibited an increased risk of fatal and/or non-fatal CVD events. Moreover, those individuals who had "more severe" NAFLD, defined based on imaging techniques plus either elevated serum gamma-glutamyltransferase concentrations or high NAFLD fibrosis score or high 2-deoxy-2-[fluorine-18]fluoro-D-glucose uptake on positron emission tomography, or by biopsy-proven fibrosis stages, were also more likely to develop fatal and non-fatal events of cardiovascular disease [135]. Therefore, modern studies seemingly confirm the historical notion that the liver is involved in cardiocirculatory physiopathology [127].

\subsection{NAFLD and Cancer}

By the early 2000s, it had already become clear that NAFLD was associated with both hepatic and extra-hepatic cancers.

\subsubsection{Hepatocellular Carcinoma}

In 2002, two seminal studies reported on the risk of hepatocellular carcinoma (HCC) developing in the setting of NAFLD.

Bugianesi et al., by retrospectively identifying 44 patients with HCC occurring in the setting of cryptogenic cirrhosis (CC) out of 641 cirrhosis-associated HCCs, observed that hypertriglyceridemia, diabetes, and normal aminotransferases were the risk factors independently associated with HCC arising in CC, suggesting that HCC may represent a late complication of NASH-cirrhosis [136].

Marrero et al., by studying 105 consecutive cases of HCC, reported that either histological or clinical features associated with NAFLD were common among patients with CC; moreover, HCCs manifesting among patients with $\mathrm{CC}$ were larger at diagnosis given that they were less likely to have undergone HCC surveillance, and therefore these were less likely to be candidates for surgical or local ablative therapies [137]. 
Presently, the development of HCC in a subset of individuals is a definite feature of the natural course of NAFLD [129]. A meta-analytic review reported that, compared to other etiologies of liver disease, in non-cirrhotic subjects, those with NASH have a higher risk of HCC [138]. The risk factors for the development of HCC in those with NAFLD include genetics, lifestyle, liver-related and metabolic determinants $[139,140]$.

\subsubsection{NAFLD and Extra-Hepatic Cancer}

In their pioneer study, Sørensen et al., by using the Danish National Registry of Patients, compared the Danish general population data of 7326 individuals who had received a hospital diagnosis of: alcoholic (ICD-8_571.10), nonalcoholic (ICD-8_571.11), or unspecified fatty liver (ICD-8_571.19) at least once during the 16-year study period. Data have shown that patients with nonalcoholic/unspecified fatty liver had an increased risk of pancreatic cancer (standardized incidence ratio (SIR) 3.0; 95\% CI, 1.3-5.8; vs. SIR 1.5; 95\% CI, 0.7-3.0) and kidney cancer (SIR 2.7; 95\% CI, 1.1-5.6) [141].

Presently, a variety of extra-hepatic cancers, including colorectal adenoma and carcinoma, are increasingly identified as a systemic manifestation of NAFLD [142,143]. Recent data suggest that NAFLD—more than obesity-is associated with an increased risk of extra-hepatic cancers, such as those of the gastrointestinal tract and uterus [144]. A meta-analytic review of observational studies of asymptomatic individuals submitted to colonoscopy, owing to screening purposes reported that NAFLD was independently associated with a mildly increased risk of incident and prevalent colorectal adenomas and cancer [145]. Various pathogenic mechanisms underlie the association of NAFLD with large bowel carcinogenesis, including sub-clinical systemic inflammation, IR, adipokines, bile acids and liver fibrosis [146,147].

\section{History of Guidelines on NAFLD Issued by Scientific Societies}

Over time, scientific societies from different geographic areas have issued guidelines focusing on the criteria for diagnosis and management of NAFLD in adults, aimed at regulating clinical decision making. It is notable that a gap of decades separates the first clinico-pathological recognitions of NAFLD from recommendations issued by scientific societies. Probably, this mirrors the initial scarcity of evidence-based data to support strong recommendations. Distinctive features of the wide spectrum of NAFLD include expanding epidemiological trajectories, continuous progress in non-invasive diagnostic tools, as well as findings from basic research and clinical therapeutic trials of novel candidate drug regimens. All these concur in rendering publications and the updating of NAFLD guidelines a formidable multidisciplinary effort and an ongoing challenge for scientific hepatological societies.

The first NAFLD guidelines were released by the Asian Pacific Association Study of the Liver (APASL) in 2007. This document was a summary of proposals by the Asian-Pacific Working Party for NAFLD, and was accompanied by reviews which summarized and annotated evidence and rationale supporting recommendations $[148,149]$. It was an informative effort directed at clinicians regarding a new globally expanding disease. Interestingly, these authors were able to find some common grounds in NAFLD management, although strong evidence was lacking at that time. This first document proposed by Asian scientific societies paved the way for the publication of clinical practice guidelines for NAFLD in Europe.

In 2010, the European Association for the Study of the Liver (EASL) issued a position statement that summarized the proceedings of the 2009 EASL Special Conference on NAFLD/NASH. This seminal article proposed expert opinion regarding different aspects of the clinical care of NAFLD patients [18].

In 2012, a NAFLD guidelines document was published as a collaborative effort from the three major American hepatological societies: American Association for the Study of Liver Diseases (AASLD), American College of Gastroenterology and American Gastroenterological Association [150]. These comprehensive guidelines included an extensive scientific literature search and followed the standard Grading of Recommendation Assessment, Development and Evaluation (GRADE) methodology [151]. 
To complete this first set of international NAFLD guidelines, in 2014, The World Gastroenterology Organization published a global NAFLD guidelines document, which is unique in following a resource-sensitive approach, i.e., a hierarchical set of diagnostic, therapeutic, and management options to deal with risk and disease, ranked by the resources available (Cascade) [152].

Between 2007 and 2014, either consensus statements or practice guidelines based on the recommendations of national societies were also issued. These include: the Italian Association for the Study of the Liver (AISF) in 2010 [153], the Chinese Association of The Study of Liver Disease in 2011 [154], the Korean Association for the Study of the Liver in 2013 [155], and the Japanese Society of Gastroenterology and the Japanese Society of Hepatology in 2015 [156].

The abundance and worldwide circulation of international and national guidelines witness that NAFLD is a global challenge. Concurrently, the high number and scientific standard of basic studies, clinical trials and informative review articles collectively attest that NAFLD remains an open and evolving paradigm for clinicians, needing further multidisciplinary approaches aimed at addressing the pathogenic heterogeneity, the multiple metabolic risk factors and the rapid epidemiological diffusion of disease. Major breakthroughs in our understanding of disease and evolving the medical practice fully justify a continuous updating of guidelines. Between 2016 and 2018, EASL, APASL and AASLD published the update of their first set of clinical recommendations. In particular, EASL worked in collaboration with the European Association for the Study of Diabetes and the European Association for the Study of Obesity, in developing the first multidisciplinary clinical practice guidelines on NAFLD in 2016 [157]. The 2016 EASL guidelines pay special attention to NAFLD screening in the population at risk. In 2018, APASL and AASLD published new consensus statements based on the most recent evidence [158-160].

Moreover, additional national societies either published novel or updated previous documents or guidelines. This is the case for NICE guidelines in 2016 [161], AISF in 2017 [129] and the Spanish Association for the Study of the Liver in 2018 [162]. Table 4 [18,129,149,150,152-163] is a synopsis of all the published guidelines.

The comparative analysis of NAFLD guidelines is an informative academic practice, identifying both shared and diverging key points [164]. The most updated of such comparative studies clearly highlights differences in the definition of alcohol threshold, choice of screening methods, identification of the best non-invasive tool for detecting liver fibrosis and the discussion of different pharmacological approaches [165]. There is general agreement regarding the notion that non-invasive tools such as NAFLD fibrosis score (NFS) and Fibrosis 4 score (FIB-4) and transient elastography or MRI should be used to detect patients with significant liver fibrosis. Moreover, scientific societies also agree that lifestyle changes, including healthy diet, habitual physical activity and weight loss are the mainstay of treatment. However, global management of NAFLD patients still varies across different geographical areas and different national healthcare systems $[165,166]$.

It is expected that translation into clinical practice of those shared recommendations may result in improving homogeneity in NAFLD management, as well as improved outcomes in clinical trials.

Although NAFLD has epidemic proportions in adults, children are not spared either [167]. Additionally, pediatric NAFLD has distinctive histological and pathogenic features, and is an ever escalating cause of chronic liver disease, with the potential of impacting health outcomes in adolescents and young adults [168]. This justifies the publication of NAFLD guidelines from pediatric scientific societies.

In 2017, practice guidelines on this topic were published by the North American Society for Pediatric Gastroenterology, Hepatology, Nutrition (NASPGHAN) and the update of AASLD guidelines on NAFLD included a pediatric section; this is a significant step towards providing diagnostic and therapeutic tools to optimize clinical care in children. The open questions in children are similar to those in adult populations: the identification of risk factors, screening strategies and screening tests, reference standard for the diagnosis, non-invasive biomarkers and imaging; lifestyle modifications as the first-line approach $[160,169]$. 
Table 4. Guidelines, ordered by year of publication, published in English by different national and international Scientific Societies on NAFLD in adult population.

\begin{tabular}{|c|c|c|}
\hline Year-Author [Ref] & Scientific Societies & Title \\
\hline 2007-Chitturi [149] & APASL & $\begin{array}{l}\text { NAFLD in the Asia-Pacific region: definitions and } \\
\text { overview of proposed guidelines. }\end{array}$ \\
\hline 2010_Ratziu [18] & EASL & $\begin{array}{l}\text { A position statement on NAFLD/NASH based on the } \\
\text { EASL } 2009 \text { special conference. }\end{array}$ \\
\hline 2010_Loria [153] & AISF & $\begin{array}{l}\text { Practice guidelines for the diagnosis and } \\
\text { management of NAFLD. A decalogue from the AISF } \\
\text { Expert Committee. }\end{array}$ \\
\hline 2011-Fan [154] & $\begin{array}{l}\text { Chinese Association of } \\
\text { The Study of Liver } \\
\text { Disease }\end{array}$ & $\begin{array}{l}\text { Guidelines for the diagnosis and management of } \\
\text { nonalcoholic fatty liver disease: update } 2010\end{array}$ \\
\hline 2012-Chalasani [150] & AASLD-ACG-AGA & $\begin{array}{l}\text { The diagnosis and management of non-alcoholic } \\
\text { fatty liver disease: practice guideline by the AASLD, } \\
\text { ACG and AGA. }\end{array}$ \\
\hline 2013-Lee [155] & KASL & $\begin{array}{l}\text { KASL clinical practice guidelines: Management of } \\
\text { nonalcoholic fatty liver disease. }\end{array}$ \\
\hline 2014—LaBrecque [152] & WGO & $\begin{array}{l}\text { World Gastroenterology Organisation global } \\
\text { guidelines: Nonalcoholic fatty liver disease and } \\
\text { non-alcoholic steatohepatitis. }\end{array}$ \\
\hline 2015-Watanabe [156] & $\begin{array}{l}\text { Japanese Society of } \\
\text { Gastroenterology and } \\
\text { The Japanese Society of } \\
\text { Hepatology }\end{array}$ & $\begin{array}{c}\text { Evidence-based clinical practice guidelines for } \\
\text { nonalcoholic fatty liver disease/nonalcoholic } \\
\text { steatohepatitis. }\end{array}$ \\
\hline 2016-[Marchesini] [157] & EASL-EASD-EASO & $\begin{array}{l}\text { EASL-EASD-EASO Clinical Practice Guidelines for } \\
\text { the management of non-alcoholic fatty liver disease. }\end{array}$ \\
\hline $\begin{array}{l}\text { 2016-no authors listed } \\
\text { [161] }\end{array}$ & NICE & $\begin{array}{l}\text { Non-Alcoholic Fatty Liver Disease: Assessment and } \\
\text { Management. }\end{array}$ \\
\hline 2017—Lonardo [129] & AISF & $\begin{array}{l}\text { AISF position paper on NAFLD: Updates and future } \\
\text { directions. }\end{array}$ \\
\hline 2018-Chalasani [160] & AASLD & $\begin{array}{l}\text { The diagnosis and management of nonalcoholic fatty } \\
\text { liver disease: Practice guidance from the AASLD. }\end{array}$ \\
\hline 2018-Wong [158] & $\begin{array}{l}\text { Asia-Pacific Working } \\
\text { Party on Non-alcoholic } \\
\text { Fatty Liver Disease }\end{array}$ & $\begin{array}{l}\text { Asia-Pacific Working Party on NAFLD guidelines } \\
\text { 2017-Part 1: Definition, risk factors and assessment. }\end{array}$ \\
\hline 2018-Chitturi [159] & $\begin{array}{l}\text { Asia-Pacific Working } \\
\text { Party on NAFLD }\end{array}$ & $\begin{array}{l}\text { The Asia-Pacific Working Party on Non-alcoholic } \\
\text { Fatty Liver Disease guidelines 2017-Part 2: } \\
\text { Management and special groups. }\end{array}$ \\
\hline 2018-Aller [162] & $\begin{array}{l}\text { Spanish Association for } \\
\text { the Study of the Liver }\end{array}$ & Consensus document. Management of NAFLD. \\
\hline 2019-Alswat [163] & $\begin{array}{l}\text { Saudi Association for the } \\
\text { Study of Liver Diseases } \\
\text { and Transplantation }\end{array}$ & $\begin{array}{l}\text { Position statement on the diagnosis and management } \\
\text { of NAFLD. }\end{array}$ \\
\hline
\end{tabular}

AASLD—American Association for the study of Liver Disease; ACG-American College of Gastroenterology; AGA-American Gastroenterological Association; AISF-Italian Association for the Study of the Liver; APASL-Asian Pacific Association Study of the Liver; EASD-European Association for the Study of Diabetes; EASL-European Association for the Study of the Liver; EASO-European Association for the Study of Obesity; KASL-Korean Association for the Study of the Liver; NAFLD—nonalcoholic fatty liver disease; NASH—nonalcoholic steatohepatitis; NICE—National Institute for Health and Care Excellence (UK); WGO—World Gastroenterology Organization. 


\section{History of General, Cellular and Molecular Pathogenesis of NAFLD and NASH}

Our understanding of the level of complexity of NAFLD pathogenesis has increased over time. While the earliest view had indicated the mechanistic development of steatohepatitis as a simple "two-hit" phenomenon, i.e., cell insults such as oxidative stress, lipid oxidation and inflammation superimposed on steatosis caused by IR [170], subsequent theories have clearly elucidated a more sophisticated level of complexity. In their seminal paper, Tilg and Moschen proposed that, irrespective of whether inflammation chronologically precedes or follows steatosis, many parallel hits of intestinal and/or adipose tissue origin, endoplasmic reticulum stress, (adipo)cytokines and innate immunity act in concert to regulate the distinctive features of NASH [171]. This "multiple hits hypothesis" continues to maintain its scientific credibility [172].

It would be difficult or even impossible to summarize here all the individual scientific contributions that, over time, have facilitated a more in-depth understanding of NAFLD and NASH pathogenesis. Excellent reviews may be consulted to this end [173-175]. That said, however, certain particularly innovative lines of research developed by distinguished groups of authors are acknowledged in Table 5 .

Table 5. Principal advancements in cellular and molecular pathogenesis of NAFLD and NASH.

\begin{tabular}{|c|c|c|}
\hline Years-Authors [Ref] & Topic & Comment \\
\hline $\begin{array}{l}\text { 1999-2009-Caldwell; Leclerq; } \\
\text { Robertson; Sanyal; Parardis; } \\
\text { Crespo; Marra; Caldwell [176-183] }\end{array}$ & $\begin{array}{l}\text { Oxidative stress and } \\
\text { molecular fibrogenesis }\end{array}$ & $\begin{array}{c}\text { A seminal line of research investigating the } \\
\text { interconnections between metabolic } \\
\text { dysregulation, hepatocyte mitochondrial } \\
\text { abnormalities, TNF-alpha and fibrogenesis. } \\
\text { These studies identify molecular pathways } \\
\text { to be targeted for effective NASH drug } \\
\text { treatment. }\end{array}$ \\
\hline $\begin{array}{c}\text { 2004-2005-Targher, Kaser; } \\
\text { Pagano; Vuppalanchi; Bugianesi; } \\
\text { Targher [184-189] }\end{array}$ & Adiponectin & $\begin{array}{l}\text { Adiponectin is an adipokine with } \\
\text { anti-inflammatory and anti-steatotic } \\
\text { properties. Hypoadiponectinemia is a } \\
\text { feature of NAFLD. Adiponectin may also be } \\
\text { associated with specific features of liver } \\
\text { histology in NASH. }\end{array}$ \\
\hline 2005 Younossi; [190,191] & $\begin{array}{c}\text { Genomic/proteomic } \\
\text { analysis to } \\
\text { obesity-related NAFLD }\end{array}$ & $\begin{array}{l}\text { The molecular pathogenesis of disease was } \\
\text { investigated by evaluating those } \\
\text { differentially expressed genes/gene } \\
\text { products in patients with NASH. These are } \\
\text { related to lipid metabolism and } \\
\text { extracellular matrix remodeling. Moreover, } \\
\text { genes involved in liver regeneration, } \\
\text { apoptosis, and the detoxification process } \\
\text { were also differentially expressed. }\end{array}$ \\
\hline 2005 - Baffy [192] & UCP2 & $\begin{array}{l}\text { UCP2 is a widely distributed fatty } \\
\text { acid-responsive carrier protein of the } \\
\text { mitochondrial inner membrane. It is } \\
\text { substantially increased in fatty liver where } \\
\text { it may play a role at multiple steps } \\
\text { including lipid metabolism, mitochondrial } \\
\text { bioenergetics, oxidative stress, apoptosis, } \\
\text { and carcinogenesis. }\end{array}$ \\
\hline
\end{tabular}


Table 5. Cont.

\begin{tabular}{|c|c|c|}
\hline Years-Authors [Ref] & Topic & Comment \\
\hline $\begin{array}{l}2007 \text { - 2011 Puri; } \\
\text { Puri; Fon Tacer; Bell [193-196] }\end{array}$ & $\begin{array}{l}\text { Lipid deregulation and } \\
\text { peroxidation are key } \\
\text { features of NASH }\end{array}$ & $\begin{array}{l}\text { Multiple alterations in the hepatic lipid } \\
\text { composition characterize NAFLD. } \\
\text { Moreover, the progression of NASH is } \\
\text { associated with impaired PUFA metabolism } \\
\text { and non-enzymatic oxidation. Perturbed } \\
\text { lipid and lipoprotein metabolism } \\
\text { accompanied by chronic inflammation is } \\
\text { the central molecular pathway for the } \\
\text { development of MetS-related diseases, } \\
\text { including atherosclerosis, CVD and NAFLD. } \\
\text { Hepatic lipid peroxidation is increased in } \\
\text { children with NAFLD. }\end{array}$ \\
\hline $\begin{array}{l}\text { 2005-2009-Feldstein and Gores; } \\
\text { Malhi and Gores; Gentile and } \\
\text { Pagliassotti; Farrell [197-200] }\end{array}$ & $\begin{array}{c}\text { Apoptosis and molecular } \\
\text { mechanisms of } \\
\text { lipotoxicity and ER } \\
\text { stress. }\end{array}$ & $\begin{array}{l}\text { Apoptosis is a specific form of cell death } \\
\text { that plays a key role in the pathogenesis of } \\
\text { NAFLD. The subcellular and molecular } \\
\text { mechanisms involved in triggering } \\
\text { hepatocyte apoptosis are pinpointed. FFAs } \\
\text { directly activate the proapoptotic protein } \\
\text { Bax, in a c-jun N-terminal kinase-dependent } \\
\text { manner. Moreover, FFAs activate the } \\
\text { lysosomal pathway of cell death and } \\
\text { regulate death receptor gene expression. } \\
\text { Saturated fatty acids may represent the } \\
\text { "second hit" hastening the development of } \\
\text { NASH. }\end{array}$ \\
\hline
\end{tabular}

PPARs are nuclear hormone receptors. These, by acting as intracellular sensors for

PPARs a variety of lipophilic molecules including cholesterol metabolites, and FFAs, play key roles in regulating energy homeostasis, steatogenesis, inflammation and IR.

These studies focus on the role of dietary fat, adipocytokines and the SREBP-1c in the association of IR and steatosis. Importantly, it is shown that IR in humans is best

2008-2011 Gronbaek; Kumashiro [203,204]

Molecular mechanisms linking NAFLD with IR and T2D. predicted by DAG content in hepatic lipid droplets supporting the notion that NAFLD-associated IR is caused by an increase in hepatic DAG content, which results in the activation of $\mathrm{PKC} \varepsilon$.

TLRs (especially TLR4) activate Kuppffer cells following the recognition of danger signals. In NAFLD, this process may be perturbed at multiple steps owing to altered 2009_Baffy [205] Role of Kuppffer cells sinusoid microcirculation and impaired hepatocellular clearance of exogenous and endogenous danger signals; deranged lipid homeostasis; perturbed adipokine secretion and increased production of ROS.

First evidence in humans that NAFLD is associated with increased gut permeability caused by disruption of intercellular tight 2009-Miele [206] Intestinal permeability junctions in the intestine, and leading to an increased prevalence of SIBO in these patients therefore contributing to the pathogenesis of hepatic fat deposition. 
Table 5. Cont.

\begin{tabular}{|c|c|c|}
\hline Years-Authors [Ref] & Topic & Comment \\
\hline 2009_Syn [207] & Hh-mediated EMT & $\begin{array}{l}\text { Based on cell cultures and mouse NAFLD } \\
\text { models it is concluded that Hh-mediated } \\
\text { EMT in ductular cells contributes to the } \\
\text { pathogenesis of cirrhosis in NAFLD. }\end{array}$ \\
\hline 2010_Cheung [208] & miRNA & $\begin{array}{l}\text { Progress in miRNA research allows the } \\
\text { molecular characterization of events that } \\
\text { limit protein expression, which is key in } \\
\text { NAFLD development and progression. }\end{array}$ \\
\hline 2011-2013-Van Rooyen [209-211] & Free cholesterol & $\begin{array}{l}\text { This milestone research has consistently } \\
\text { shown that SREBP-2 connects IR, hepatic } \\
\text { cholesterol, and inflammation in NASH; } \\
\text { that the cause of NASH in an experimental } \\
\text { obese, diabetic mouse model is the } \\
\text { accumulation of hepatic free cholesterol; } \\
\text { and that cholesterol lowering with a } \\
\text { combination of ezetimibe/atorvastatin } \\
\text { reverses hepatic free cholesterol which } \\
\text { dampens JNK activation, ALT release, } \\
\text { hepatocyte apoptosis, and inflammatory } \\
\text { changes, collectively leading to the reversal } \\
\text { of fibrosing NASH in obese, diabetic mice } \\
\text { with MetS. }\end{array}$ \\
\hline 2013-Pirola [212] & $\begin{array}{l}\text { Epigenetic modification } \\
\text { of liver mitochondrial } \\
\text { DNA }\end{array}$ & $\begin{array}{l}\text { Hepatic methylation and transcriptional } \\
\text { activity of the mitochondrially encoded } \\
\text { NADH dehydrogenase } 6 \text { are associated } \\
\text { with the severity of NAFLD histology. }\end{array}$ \\
\hline 2015-Kasumov [213] & $\begin{array}{l}\text { Ceramides are key } \\
\text { mediators of } \\
\text { cardio-metabolic risk in } \\
\text { NAFLD }\end{array}$ & $\begin{array}{l}\text { In LDLR(-/-) mice, a western diet-induced } \\
\text { model of NAFLD and atherosclerosis } \\
\text { caused hepatic oxidative stress, } \\
\text { inflammation, apoptosis, increased hepatic } \\
\text { long-chain ceramides associated with } \\
\text { apoptosis (C16 and C18) and decreased } \\
\text { very-long-chain ceramide (C24) involved in } \\
\text { insulin signaling. The plasma ratio of } \\
\text { ApoB/ApoA1 (proteins of VLDL/LDL and } \\
\text { HDL) was doubled due to increased ApoB } \\
\text { production. } \\
\text { Myriocin decreased lipogenesis, ApoB } \\
\text { production and increased HDL turnover. } \\
\text { These changes translated into reduced } \\
\text { hepatic and plasma ceramides and } \\
\text { sphingomyelin, and decreased } \\
\text { atherosclerosis, hepatic steatosis, fibrosis, } \\
\text { and apoptosis. }\end{array}$ \\
\hline 2018-Kutlu [214] & Cancerogenesis & $\begin{array}{l}\text { Molecular signaling pathways involved in } \\
\text { NASH-derived HCC include genetic or } \\
\text { epigenetic modifications and alterations in } \\
\text { metabolic, immunologic and endocrine } \\
\text { pathways that are closely associated with } \\
\text { inflammation, liver injury and fibrosis in } \\
\text { NASH. }\end{array}$ \\
\hline
\end{tabular}


Table 5. Cont.

\begin{tabular}{ccc}
\hline Years-Authors [Ref] & Topic & Comment \\
\hline 2020-Hernández [215] & $\begin{array}{c}\text { EVs are emerging as key } \\
\text { players in the molecular } \\
\text { pathogenesis of NAFLD }\end{array}$ & $\begin{array}{c}\text { EVs contain a variety of bioactive molecules } \\
\text { (e.g., proteins, lipids, coding and } \\
\text { non-coding RNAs and mitochondrial DNA) } \\
\text { that exert a key role in cell-to-cell } \\
\text { communication via the secretion by } \\
\text { different cell types. Stressed/damaged } \\
\text { hepatocytes release large quantities of EVs } \\
\text { that contribute to the progression of liver } \\
\text { disease by affecting inflammation, } \\
\text { fibrogenesis and angiogenesis. }\end{array}$ \\
\hline
\end{tabular}

\begin{abstract}
ApoB—apolipoprotein B; ALT—alanine transaminase; CVD—cardiovascular disease; EMT—epithelial-mesenchimal transition; ER — endoplasmic reticulum stress; EVs—extracellular vesicles; FFAs—-free fatty acids; HCC — hepatocellular carcinoma; HDL—high-density lipoprotein; Hh—hedgehog; IR—insulin resistance; JNK—c-Jun N-terminal kinase; LDLR—low-density lipoprotein receptor; MetS-metabolic syndrome; miRNA-microRNA; $\mathrm{NASH}$-nonalcoholic steatohepatitis; PKC $\varepsilon$ - protein kinase $\mathrm{C} \varepsilon$; PPARs-peroxisome proliferators-activated receptors; PUFA—polyunsaturated fatty acid; ROS-reactive oxygen species; SIBO-small intestine bacterial overgrowth; SREBP-1c-sterol regulatory element-binding protein-1c; TLRs-toll-like receptors; T2D-type 2 diabetes; UCP 2-uncoupling protein-2.
\end{abstract}

\title{
6. Conclusions
}

Words of caution have recently been spent by eminent researchers regarding the risks inherent in a premature change of NAFLD nomenclature [216]. NAFLD and MAFLD are not exactly the same disease. A recent study conducted in 13,083 cases extracted from the NHANES III data has clearly documented this notion, by showing that MAFLD is more likely to capture those patients with hepatic steatosis, who exhibit a higher risk of disease progression [217]. Should these findings be confirmed, our understanding of relevant features of NAFLD, such as natural history and treatment response rates to lifestyle changes and experimental drug agents, may likely be in need of reassessment, if the MAFLD definition is accepted.

We have tried to recapitulate the chief historical advancements in NAFLD, spanning histology, pathophysiology, pathogenesis and guidelines. We apologize to all those eminent authors who, inadvertently, are not mentioned here: their contributions have been acknowledged elsewhere [218]. Our review article has shown that there are some unsettled issues in the history of metabolic syndrome: why, for example, were ancient Indo-European physicians apparently aware of its existence (Table 2), whereas ancient Egyptian physicians were not? [219,220]. Is this a clue to a healthy diet? [219]; or, does this result from North Africans being genetically spared from NAFLD and hence the MetS [24,221]?

An analysis of historical perspectives of disease has also revealed that many lines of current research, such as clinico-pathological correlations, personalized medicine, and sex differences are deeply eradicated in NAFLD history ( Table 2; Table 3). On these grounds, we emphasize that understanding the historical lines of research which have eventually conducted to present views may assist, particularly but not only, younger researchers, toward identifying the most appropriate research strategies to innovate, by giving significance to the past [32]. Stated otherwise, as summarized in this adage attributed to Johann Wolfgang Goethe, "The history of a science is that science itself".

Author Contributions: A.L. and Y.F. first discussed the idea behind this article and selected co-authors. A.L. wrote the first draft of the manuscript, including Sections 1, 3, 5 and 6. Y.F. and K.A.A. wrote the first draft of Section 2. S.L. wrote the first draft of Section 4. All authors jointly reworked the first draft of the manuscript and contributed to retrieving additional references, as well as answering reviewers' and editors' comments. All authors have read and agreed to the published version of the manuscript.

Funding: This research received no external funding.

Acknowledgments: We are indebted to Jacqueline Mole for her careful editing of English.

Conflicts of Interest: The authors declare no conflict of interest. 


\section{References}

1. Eslam, M.; Sanyal, A.J.; George, J. MAFLD: A consensus-driven proposed nomenclature for metabolic associated fatty liver disease. Gastroenterology 2020. [CrossRef]

2. Fouad, Y.; Waked, I.; Bollipo, S.; Gomaa, A.; Ajlouni, Y.; Attia, D. What's in a name? Renaming 'NAFLD' to 'MAFLD'. Liver Int. 2020, 40, 1254-1261. [CrossRef]

3. Addison, T. Observations on fatty degeneration of the liver. Guys Hosp. Rep. 1836, 1, 485.

4. Connor, C.L. Fatty infiltration of the liver and the development of cirrhosis in diabetes and chronic alcoholism. Am. J. Pathol. 1938, 14, 347-364.

5. Dianzani, M.U. Sulla patogenesi dell'accumulo del grasso nella steatosi epatica. Rass. Med. Sarda. 1964, 66, 67-90.

6. Adler, M.; Schaffner, F. Fatty liver hepatitis and cirrhosis in obese patients. Am. J. Med. 1979, 67, 811-816. [CrossRef]

7. Ludwig, J.; Viggiano, T.R.; McGill, D.B.; Oh, B.J. Nonalcoholic steatohepatitis: Mayo Clinic experiences with a hitherto unnamed disease. Mayo Clin. Proc. 1980, 55, 434-438.

8. Batman, P.A.; Scheuer, P.J. Diabetic hepatitis preceding the onset of glucose intolerance. Histopathology 1985, 9, 237-243. [CrossRef]

9. Schaffner, F.; Thaler, H. Nonalcoholic fatty liver disease. Prog. Liver Dis. 1986, 8, 283-298.

10. Diehl, A.M.; Goodman, Z.; Ishak, K.G. Alcohollike liver disease in nonalcoholics. A clinical and histologic comparison with alcohol-induced liver injury. Gastroenterology 1988, 95, 1056-1062. [CrossRef]

11. Lonardo, A.; Bellini, M.; Tondelli, E.; Frazzoni, M.; Grisendi, A.; Pulvirenti, M.; Della Casa, G. Nonalcoholic steatohepatitis and the "bright liver syndrome": Should a recently expanded clinical entity be further expanded? Am. J. Gastroenterol. 1995, 90, 2072-2074.

12. Mendler, M.H.; Turlin, B.; Moirand, R.; Jouanolle, A.M.; Sapey, T.; Guyader, D.; le Gall, J.Y.; Brissot, P.; David, V.; Deugnier, Y. Insulin resistance-associated hepatic iron overload. Gastroenterology 1999, 117, 1155-1163. [CrossRef]

13. Neuschwander-Tetri, B.A.; Caldwell, S.H. Nonalcoholic steatohepatitis: Summary of an AASLD Single Topic Conference. Hepatology 2003, 37, 1202-1219, Correction in 2003, 38, 536. [CrossRef]

14. Dixon, J.B.; O’Brien, P.E. Bhathal Letter. Gastroenterology 2002, 122, 841-842. [CrossRef]

15. Farrell, G.C. Non-alcoholic steatohepatitis: What is it, and why is it important in the Asia-Pacific region? J. Gastroenterol. Hepatol. 2003, 18, 124-138. [CrossRef]

16. Brunt, E.M. Nonalcoholic steatohepatitis. Semin. Liver Dis. 2004, 24, 3-20.

17. Loria, P.; Lonardo, A.; Carulli, N. Should nonalcoholic fatty liver disease be renamed? Dig. Dis. 2005, 23, 72-82. [CrossRef]

18. Ratziu, V.; Bellentani, S.; Cortez-Pinto, H.; Day, C.; Marchesini, G. A position statement on NAFLD/NASH based on the EASL 2009 special conference. J. Hepatol. 2010, 53, 372-384. [CrossRef]

19. Brunt, E.M. What's in a NAme? Hepatology 2009, 50, 663-667. [CrossRef]

20. Balmer, M.L.; Dufour, J.F. Nicht-alkoholische Steatohepatitis-von NAFLD zu MAFLD. Ther. Umsch. 2011, 68, 183-188. [CrossRef]

21. Bellentani, S.; Tiribelli, C. Is it time to change NAFLD and NASH nomenclature? Lancet. Gastroenterol. Hepatol. 2017, 2, 547-548. [CrossRef]

22. Eslam, M.; Sanyal, A.J.; George, J. Toward more accurate nomenclature for fatty liver diseases. Gastroenterology 2019, 157, 590-593. [CrossRef] [PubMed]

23. Younossi, Z.M.; Stepanova, M.; Afendy, M.; Fang, Y.; Younossi, Y.; Mir, H.; Srishord, M. Changes in the prevalence of the most common causes of chronic liver diseases in the United States from 1988 to 2008. Clin. Gastroenterol. Hepatol. 2011, 9, 524-530. [CrossRef] [PubMed]

24. Younossi, Z.M.; Koenig, A.B.; Abdelatif, D.; Fazel, Y.; Henry, L.; Wymer, M. Global epidemiology of nonalcoholic fatty liver disease-Meta-analytic assessment of prevalence, incidence, and outcomes. Hepatology 2016, 64, 73-84. [CrossRef]

25. Younossi, Z.M. Non-alcoholic fatty liver disease-A global public health perspective. J. Hepatol. 2019, 70, 531-544. [CrossRef]

26. Farrell, G.C.; Wong, V.W.; Chitturi, S. NAFLD in Asia-as common and important as in the West. Nat. Rev. Gastroenterol. Hepatol. 2013, 10, 307-318. [CrossRef] 
27. Pimpin, L.; Cortez-Pinto, H.; Negro, F.; Corbould, E.; Lazarus, J.V.; Webber, L.; Sheron, N. EASL HEPAHEALTH Steering Committee. Burden of liver disease in Europe: Epidemiology and analysis of risk factors to identify prevention policies. J. Hepatol. 2018, 69, 718-735. [CrossRef]

28. Zhou, F.; Zhou, J.; Wang, W.; Zhang, X.J.; Ji, Y.X.; Zhang, P.; She, Z.G.; Zhu, L.; Cai, J.; Li, H. Unexpected Rapid Increase in the Burden of NAFLD in China From 2008 to 2018: A Systematic Review and Meta-Analysis. Hepatology 2019, 70, 1119-1133. [CrossRef]

29. Arshad, T.; Golabi, P.; Henry, L.; Younossi, Z.M. Epidemiology of Non-alcoholic Fatty Liver Disease in North America. Curr. Pharm. Des. 2020, 26, 993-997, published ahead of print in Curr. Pharm. Des. 2020. [CrossRef]

30. Baumeister, S.E.; Völzke, H.; Marschall, P.; John, U.; Schmidt, C.O.; Flessa, S.; Alte, D. Impact of fatty liver disease on health care utilization and costs in a general population: A 5-year observation. Gastroenterology 2008, 134, 85-94. [CrossRef]

31. Stepanova, M.; De Avila, L.; Afendy, M.; Younossi, I.; Pham, H.; Cable, R.; Younossi, Z.M. Direct and indirect economic burden of chronic liver disease in the United States. Clin. Gastroenterol. Hepatol. 2017, 15, 759-766. [CrossRef] [PubMed]

32. Lonardo, A.; Ballestri, S. Perspectives of nonalcoholic fatty liver disease research: A personal point of view. Explor. Med. 2020, 1, 85-107. [CrossRef]

33. Rokitansky, C.A. Skizze der Größen und Formabweichungen der Leber. Bruchstück Med Jahrb des kaisl, königl Österr Staates 1839. Bd 29 oder neueste Folge Bd 20 Wien: 557.

34. Pepper, W. Saccharine diabetes. Med. Rec. 1884, 25, 9-12.

35. Pepper, W. A System of Practical Medicine by American Authors; Lea Brothers \& Co.: Philadelphia, PA, USA, 1885; Volume II, p. 1050.

36. Brunt, E.M.; Neuschwander-Tetri, B.A.; Burt, A.D. Fatty liver disease: Alcoholic and nonalcoholic. In MacSween's Pathology of the Liver, 6th ed.; Burt, A.D., Portmann, B., Ferrell, L., Eds.; Elsevier: Amsterdam, The Netherlands, 2011; pp. 293-359.

37. Moran, J.R.; Ghishan, F.K.; Halter, S.A.; Greene, H.L. Steatohepatitis in obese children: A cause of chronic liver dysfunction. Am. J. Gastroenterol. 1983, 78, 374-377. [PubMed]

38. Kleiner, D.E.; Brunt, E.M.; Van Natta, M.; Behling, C.; Contos, M.J.; Cummings, O.W.; Ferrell, L.D.; Liu, Y.C.; Torbenson, M.S.; Unalp-Arida, A.; et al. Design and validation of a histological scoring system for nonalcoholic fatty liver disease. Hepatology 2005, 41, 1313-1321. [CrossRef] [PubMed]

39. Bedossa, P.; FLIP Pathology Consortium. Utility and appropriateness of the fatty liver inhibition of progression (FLIP) algorithm and steatosis, activity, and fibrosis (SAF) score in the evaluation of biopsies of nonalcoholic fatty liver disease. Hepatology 2014, 60, 565-575. [CrossRef] [PubMed]

40. Brunt, E.M.; Janney, C.G.; Di Bisceglie, A.M.; Neuschwander-Tetri, B.A.; Bacon, B.R. Nonalcoholic steatohepatitis: A proposal for grading and staging the histological lesions. Am. J. Gastroenterol. 1999, 94, 2467-2474. [CrossRef]

41. Alkhouri, N.; De Vito, R.; Alisi, A.; Yerian, L.; Lopez, R.; Feldstein, A.E.; Nobili, V. Development and validation of a new histological score for pediatric non-alcoholic fatty liver disease. J. Hepatol. 2012, 57, 1312-1318. [CrossRef]

42. Sheka, A.C.; Adeyi, O.; Thompson, J.; Hameed, B.; Crawford, P.A.; Ikramuddin, S. Nonalcoholic Steatohepatitis: A review. JAMA 2020, 323, 1175-1183, Correction in JAMA 2020, 323, 1619. [CrossRef]

43. Davison, B.A.; Harrison, S.A.; Cotter, G.; Alkhouri, N.; Sanyal, A.; Edwards, C.; Colca, J.R.; Iwashita, J.; Koch, G.G.; Dittrich, H.C. Suboptimal reliability of liver biopsy evaluation has implications for randomized clinical trials. J. Hepatol. 2020. [CrossRef]

44. Eslam, M.; Alvani, R.; Shiha, G. Obeticholic acid: Towards first approval for NASH. Lancet 2019, 394, 2131-2133. [CrossRef]

45. Younossi, Z.M.; Ratziu, V.; Loomba, R.; Rinella, M.; Anstee, Q.M.; Goodman, Z.; Bedossa, P.; Geier, A.; Beckebaum, S.; Philip N Newsome, P.N.; et al. Obeticholic acid for the treatment of non-alcoholic steatohepatitis: Interim analysis from a multicentre, randomised, placebo-controlled phase 3 trial. Lancet 2019, 394, 2184-2196. [CrossRef]

46. Eslam, M.; Newsome, P.N.; Sarin, S.K.; Anstee, Q.M.; Targher, G.; Romero-Gomez, M.; Zelber-Sagi, S.; Wong, V.W.S.; Dufour, J.F.; Schattenberg, J.M.; et al. A new definition for metabolic dysfunction-associated fatty liver disease: An international expert consensus statement. J. Hepatol. 2020. [CrossRef] [PubMed] 
47. Thuluvath, P.J.; Kantsevoy, S.; Thuluvath, A.J.; Savva, Y. Is cryptogenic cirrhosis different from NASH cirrhosis? J. Hepatol. 2018, 68, 519-525. [CrossRef] [PubMed]

48. Caldwell, S.; Marchesini, G. Cryptogenic vs. NASH-cirrhosis: The rose exists well before its name. J. Hepatol. 2018, 68, 391-392. [CrossRef] [PubMed]

49. Eslam, M.; Valenti, L.; Romeo, S. Genetics and epigenetics of NAFLD and NASH: Clinical impact. J. Hepatol. 2018, 68, 268-279. [CrossRef]

50. Eslam, M.; George, J. Genetic and epigenetic mechanisms of NASH. Hepatol. Int. 2016, 10, 394-406. [CrossRef]

51. Romeo, S.; Kozlitina, J.; Xing, C.; Pertsemlidis, A.; Cox, D.; Pennacchio, L.A.; Boerwinkle, E.; Cohen, J.C.; Hobbs, H.H. Genetic variation in PNPLA3 confers susceptibility to nonalcoholic fatty liver disease. Nat. Genet. 2008, 40, 1461-1465. [CrossRef]

52. Eslam, M.; George, J. Genetic contributions to NAFLD: Leveraging shared genetics to uncover systems biology. Nat. Rev. Gastroenterol. Hepatol. 2020, 17, 40-52. [CrossRef]

53. Abul-Husn, N.S.; Cheng, X.; Li, A.H.; Xin, Y.; Schurmann, C.; Stevis, P.; Liu, P.; Kozlitina, Y.; Stender, S.; Wood, G.C.; et al. A protein-truncating HSD17B13 variant and protection from chronic liver disease. N. Engl. J. Med. 2018, 378, 1096-1106. [CrossRef]

54. Kozlitina, J.; Smagris, E.; Stender, S.; Nordestgaard, B.G.; Zhou, H.H.; Tybjærg-Hansen, A.; Vogt, T.F.; Hobbs, H.H.; Cohen, J.C. Exome-wide association study identifies a TM6SF2 variant that confers susceptibility to nonalcoholic fatty liver disease. Nat. Genet. 2014, 46, 352-356. [CrossRef] [PubMed]

55. Eslam, M.; Mangia, A.; Berg, T.; Lik, H.; Yuen, H.L.; Chan, Y.; Irving, W.L.; Dore, G.J.; Abate, M.L.; Bugianesi, E.; et al. Diverse impacts of the rs58542926 E167K variant in TM6SF2 on viral and metabolic liver disease phenotypes. Hepatology 2016, 64, 34-46. [CrossRef] [PubMed]

56. Thabet, K.; Asimakopoulos, A.; Shojaei, M.; Romero-Gomez, M.; Mangia, A.; Irving, W.L.; Thomas Berg, T.; Gregory J Dore, G.J.; Grønbæk, H.; Sheridan, D.; et al. MBOAT7 rs641738 increases risk of liver inflammation and transition to fibrosis in chronic hepatitis C. Nat. Commun. 2016, 7, 12757. [CrossRef] [PubMed]

57. Thabet, K.; Chan, H.L.Y.; Petta, S.; Mangia, A.; Berg, T.; Boonstra, A.; Brouwer, W.P.; Abate, M.L.; Wong, V.W.S.; Nazmy, M.; et al. The membrane-bound O-acyltransferase domain-containing 7 variant rs641738 increases inflammation and fibrosis in chronic hepatitis B. Hepatology 2017, 65, 1840-1850. [CrossRef]

58. Buch, S.; Stickel, F.; Trépo, E.; Way, M.; Herrmann, A.; Nischalke, H.D.; Brosch, M.; Jonas Rosendahl, J.; Berg, T.; Ridinger, M.; et al. A genome-wide association study confirms PNPLA3 and identifies TM6SF2 and MBOAT7 as risk loci for alcohol-related cirrhosis. Nat. Genet. 2015, 47, 1443-1448. [CrossRef]

59. Eslam, M.; Hashem, A.M.; Leung, R.; Romero-Gomez, M.; Berg, T.; Dore, G.; Chan, J.; Irving, H.L.K.; Sheridan, W.L.; Abate, D.M.L.; et al. Interferon- $\lambda$ rs12979860 genotype and liver fibrosis in viral and non-viral chronic liver disease. Nat. Commun. 2015, 6, 6422. [CrossRef]

60. Eslam, M.; McLeod, D.; Kelaeng, K.S.; Mangia, A.B.; Thabet, T.; Irving, K.; Dore, W.LG.J.; Sheridan, D.; Grønbæk, H.; Abate, M.L.; et al. IFN- $\lambda 3$, not IFN- $\lambda 4$, likely mediates IFNL3-IFNL4 haplotype-dependent hepatic inflammation and fibrosis. Nat. Genet. 2017, 49, 795-800. [CrossRef]

61. Metwally, M.; Bayoumi, A.; Romero-Gomez, M.; Thabet, K.; John, M.; Adams, L.A.; Huo, X.; Aller, R.; García-Monzón, C.; Arias-Loste, M.T.; et al. A polymorphism in the Irisin-encoding gene (FNDC5) associates with hepatic steatosis by differential miRNA binding to the 3'UTR. J. Hepatol. 2019, 70, 494-500. [CrossRef]

62. Lonardo, A.; Ballestri, S.; Targher, G. "Not all forms of NAFLD were created equal". Do metabolic syndrome-related NAFLD and PNPLA3-related NAFLD exert a variable impact on the risk of early carotid atherosclerosis? Atherosclerosis 2017, 257, 253-255. [CrossRef]

63. Eslam, M.; Hashem, A.M.; Romero-Gomez, M.; Berg, T.D.; Gregory, J.M.; Chan, A.; Irving, H.L.Y.; Sheridan, W.L.; Abate, D.M.L.; et al. FibroGENE: A gene-based model for staging liver fibrosis. J. Hepatol. 2016, 64, 390-398. [CrossRef]

64. Eslam, M.; George, J. Genome-Wide Association Studies and Hepatitis C: Harvesting the Benefits of the Genomic Revolution. Semin. Liver Dis. 2015, 35, 402-420. [CrossRef] [PubMed]

65. Khera, A.V.; Chaffin, M.; Aragam, K.G.; Haas, M.E.; Roselli, C.; Choi, S.H.; Natarajan, P.; Lander, E.S.; Lubitz, S.A.; Ellinor, P.T. Genome-wide polygenic scores for common diseases identify individuals with risk equivalent to monogenic mutations. Nat. Genet. 2018, 50, 1219-1224. [CrossRef] [PubMed]

66. Martin, A.R.; Kanai, M.; Kamatani, Y.; Okada, Y.; Neale, B.M.; Daly, M.J. Clinical use of current polygenic risk scores may exacerbate health disparities. Nat. Genet. 2019, 51, 584-591. [CrossRef] [PubMed] 
67. Eslam, M.; George, J. Genetic insights for drug development in NAFLD. Trends Pharmacol. Sci. 2019, 40, 506-516. [CrossRef]

68. Bayoumi, A.; Grønbæk, H.; George, J.; Eslam, M. The Epigenetic Drug Discovery Landscape for Metabolic-associated Fatty Liver Disease. Trends Genet. 2020, 36, 429-441. [CrossRef]

69. Haslam, D. Diabesty-A historical perspective: Part I. Diabesity Pract. 2012, 1, 141-145.

70. Haslam, D.; Rigby, N. A long look at obesity. Lancet 2010, 376, 85-86. [CrossRef]

71. Scholtz, M. Hippocrates' Aphorisms. Cal. West. Med. 1940, 52, 125-126.

72. Morgagni, J.B. The Seats and Causes of Diseases Investigated by Anatomy (De Sedibus et Causis Morborum per Anatomen indagata), 2nd ed.; Remondini: Padova, Italy, 1765; Volume 1.

73. Enzi, G.; Busetto, L.; Inelmen, E.M.; Coin, A.; Sergi, G. Historical Perspective: Visceral Obesity and Related Comorbidity in Joannes Baptista Morgagni's ‘De Sedibus Et Causis Morborum Per Anatomen Indagata'. Int. J. Obes. Relat. Metab. Disord. 2003, 27, 534-535. [CrossRef]

74. Haslam, D. Diabesity-A historical perspective: Part II. Diabesity Pract. 2013, 2, 23-28.

75. Vague, J. La différenciation sexuelle; facteur déterminant des formes de l'obésité. Presse. Med. 1947, 55, 339. [PubMed]

76. Bray, G.A. Body fat distribution and the distribution and the distribution of scientific knowledge. Obes. Res. 1996, 4, 189-192. [CrossRef] [PubMed]

77. Vague, J. The degree of masculine differentiation of obesities. A factor determining predisposition to diabetes, atherosclerosis, gout and uric calculous disease. Am. J. Clin. Nutr. 1956, 4, 20-34. [CrossRef] [PubMed]

78. Avogaro, P.; Crepaldi, G.; Enzi, G.; Tiengo, A. Associazione di iperlipemia, diabete mellito e obesita' di medio grado. Acta. Diabetol. Lat. 1967, 4, 572-590. [CrossRef]

79. Feldman, R.; Sender, A.J.; Siegelaub, A.B. Difference in diabetic and nondiabetic fat distribution patterns by skinfold measurements. Diabetes 1969, 18, 478-486. [CrossRef]

80. Kissebah, A.H.; Vydelingum, N.; Murray, R.; Evans, D.J.J.; Hartz, A.; Kalkhoff, R.K.; Adams, P.W. Relation of body fat distribution to metabolic complications of obesity. J. Clin. Endocrinol. Metab. 1982, 54, 254-260. [CrossRef]

81. Krotkiewski, M.; Björntorp, P.; Sjöström, L.; Smith, U. Impact of obesity on metabolism in men and women. Importance of regional adipose tissue distribution. J. Clin. Investig. 1983, 72, 1150-1162. [CrossRef]

82. Larsson, B.; Svärdsudd, K.; Welin, L.; Wilhelmsen, L.; Björntorp, P.; Tibblin, G. Abdominal adipose tissue distribution, obesity, and risk of cardiovascular disease and death: 13 year follow up of participants in the study of men born in 1913. Br. Med. J. (Clin. Res. Ed.) 1984, 288, 1401-1404. [CrossRef]

83. Fujioka, S.; Matsuzawa, Y.; Tokunaga, K.; Tarui, S. Contribution of intra-abdominal fat accumulation to the impairment of glucose and lipid metabolism in human obesity. Metabolism 1987, 36, 54-59. [CrossRef]

84. Reaven, G.M. Role of insulin resistance in human disease. Diabetes 1988, 37, 1595-1607. [CrossRef]

85. Kaplan, N.M. The deadly quartet. Upper-body obesity, glucose intolerance, hypertriglyceridemia, and hypertension. Arch. Intern. Med. 1989, 149, 1514-1520. [CrossRef] [PubMed]

86. Ferrannini, E.; Haffner, S.M.; Mitchell, B.D.; Stern, M.P. Hyperinsulinaemia: The key feature of a cardiovascular and metabolic syndrome. Diabetologia 1991, 34, 416-422. [CrossRef] [PubMed]

87. WHO Alberti and Zimmet Definition, Diagnosis and Classification of Diabetes Mellitus and Its Complications. Part 1: Diagnosis and Classification of Diabetes Mellitus Provisional Report of a WHOConsultation. Available online: https://apps.who.int/iris/bitstream/handle/10665/66040/WHO_NCD_NCS_99.2.pdf?sequence=1\& isAllowed $=\mathrm{y}$ (accessed on 2 July 2020).

88. Balkau, B.; Charles, M.A. Comment on the provisional report from the WHO consultation: European Group for the Study of Insulin Resistance (EGIR). Diabet. Med. 1999, 16, 442-443. [PubMed]

89. Expert Panel on Detection, E. Executive summary of the third report of the National Cholesterol Education Program (NCEP) Expert Panel on Detection, Evaluation, And Treatment of High Blood Cholesterol in Adults (Adult Treatment Panel III). JAMA 2001, 285, 2486-2497.

90. Ford, E.S.; Giles, W.H.; Dietz, W.H. Prevalence of the metabolic syndrome among US adults: Findings from the Third National Health and Nutrition Examination Survey. JAMA 2002, 287, 356-359. [CrossRef] [PubMed]

91. Grundy, S.M.; Brewer, H.B., Jr.; Cleeman, J.I.; Smith, S.C., Jr.; Lenfant, C. Definition of metabolic syndrome. Report of the National Heart, Lung, and Blood Institute/American Heart Association Conference on scientific issues related to definition. Circulation 2004, 109, 433-438. [CrossRef] 
92. Grundy, S.M. Diagnosis and management of the metabolic syndrome: A statement for health care professionals: An American heart association/National heart, lung, and blood institute scientific statement. Circulation 2005, 112, 2735-2752. [CrossRef]

93. Kahn, R.; Buse, J.; Ferrannini, E.; Stern, M. The metabolic syndrome: Time for a critical appraisal. Joint statement from the American Diabetes Association and the European Association for the Study of Diabetes. Diabetes Care 2005, 28, 2289-2304. [CrossRef]

94. Lonardo, A.; Ballestri, S.; Marchesini, G.; Angulo, P.; Loria, P. Nonalcoholic fatty liver disease: A precursor of the metabolic syndrome. Dig. Liver Dis. 2015, 47, 181-190. [CrossRef]

95. Reaven, G.M. The Metabolic Syndrome: Requiescat in Pace. Clin. Chem. 2005, 51, 931-938. [CrossRef]

96. Alberti, K.G.; Eckel, R.H.; Grundy, S.M.; Zimmet, P.Z.; Cleeman, J.I.; Donato, K.A.; Fruchart, J.C.; James, W.P.; Loria, C.M.; Smith, S.C. Jr.; et al. Harmonizing the metabolic syndrome: A joint interim statement of the International Diabetes Federation Task Force on Epidemiology and Prevention; National Heart, Lung, and Blood Institute; American Heart Association; World Heart Federation; International Atherosclerosis Society; and International Association for the Study of Obesity. Circulation 2009, 120, 1640-1645. [PubMed]

97. Simmons, R.K.; Alberti, K.G.; Gale, E.A.; Colagiuri, S.; Tuomilehto, J.; Qiao, Q.; Ramachandran, A.; Tajima, N.; Mirchov, I.B.; Ben-Nakhi, A.; et al. The metabolic syndrome: Useful concept or clinical tool? Report of a WHO Expert Consultation. Diabetologia 2010, 53, 600-605. [CrossRef] [PubMed]

98. Lopes, H.F.; Corrêa-Giannella, M.L.; Consolim-Colombo, F.M.; Egan, B.M. Visceral adiposity syndrome. Diabetol. Metab. Syndr. 2016, 8, 40-48. [CrossRef] [PubMed]

99. Sarafidis, P.A.; Nilsson, P.M. The metabolic syndrome: A glance at its history. J. Hypertens 2006, 24, 621-626. [CrossRef]

100. Preble, W.E., Jr. Obesity: Observations on one thousand cases. Boston Med. Surg. J. 1923, 188, 617-621. [CrossRef]

101. Zelman, S. The liver in obesity. AMA Arch. Intern. Med. 1952, 90, 141-156. [CrossRef]

102. Beringer, A.; Thaler, H. Relationships between diabetes mellitus and fatty liver. Dtsch. Med. Wochenschr. 1970, 95, 836-838. [CrossRef]

103. Haller, H. Epidemiology and associated risk factors of hyperlipoproteinemia. Z. Gesamte. Inn. Med. 1977, 32, 124-128.

104. Itoh, S.; Tsukada, Y.; Motomura, Y.; Ichinoe, A. Five patients with nonalcoholic diabetic cirrhosis. Acta Hepatogastroenterol. 1979, 26, 90-97.

105. Lee, R.G. Nonalcoholic steatohepatitis: A study of 49 patients. Hum. Pathol. 1989, 20, 594-598. [CrossRef]

106. Powell, E.E.; Cooksley, W.G.; Hanson, R.; Searle, J.; Halliday, J.W.; Powell, L.W. The natural history of nonalcoholic steatohepatitis: A follow-up study of forty-two patients for up to 21 years. Hepatology 1990, 11, 74. [CrossRef] [PubMed]

107. Bacon, B.R.; Farahvash, M.J.; Janney, C.G.; Neuschwander-Tetri, B.A. Nonalcoholic steatohepatitis: An expanded clinical entity. Gastroenterology 1994, 107, 1103-1109. [CrossRef]

108. Cortez-Pinto, H.; Camilo, M.E.; Baptista, A.; De Oliveira, A.G.; De Moura, M.C. Non-alcoholic fatty liver: Another feature of the metabolic syndrome? Clin. Nutr. 1999, 18, 353-358. [CrossRef]

109. Lonardo, A. Fatty liver and nonalcoholic steatohepatitis. Where do we stand and where are we going? Dig. Dis. 1999, 17, 80-89. [CrossRef] [PubMed]

110. Marchesini, G.; Brizi, M.; Morselli-Labate, A.M.; Bianchi, G.; Bugianesi, E.; McCullough, A.J.; Forlani, G.; Melchionda, N. Association of nonalcoholic fatty liver disease with insulin resistance. Am. J. Med. 1999, 107, 450-455. [CrossRef]

111. Marceau, P.; Biron, S.; Hould, F.S.; Marceau, S.; Simard, S.; Thung, S.; Kral, N.J.G. Liver pathology and the metabolic syndrome X in severe obesity. J. Clin. Endocrinol. Metab. 1999, 84, 1513-1517. [CrossRef]

112. Lonardo, A.; Loria, P.; Leonardi, F.; Borsatti, A.; Neri, P.; Pulvirenti, M.; Verrone, A.M.; Bagni, A.; Bertolotti, M.; Ganazzi, D.; et al. Fasting insulin and uric acid levels but not indices of iron metabolism are independent predictors of non-alcoholic fatty liver disease. A case-control study. Dig. Liver. Dis. 2002, 34, $204-211$. [CrossRef]

113. Donati, G.; Stagni, B.; Piscaglia, F.; Venturoli, N.; Morselli-Labate, A.M.; Rasciti, L.; Bolondi, L. Increased prevalence of fatty liver in arterial hypertensive patients with normal liver enzymes: Role of insulin resistance. Gut 2004, 53, 1020-1023. [CrossRef] 
114. Suzuki, A.; Angulo, P.; Lymp, J.; St Sauver, J.; Muto, A.; Okada, T.; Lindor, K. Chronological development of elevated aminotransferases in a nonalcoholic population. Hepatology 2005, 41, 64-71. [CrossRef]

115. Kotronen, A.; Westerbacka, J.; Bergholm, R.; Pietiläinen, K.H.; Yki-Järvinen, H. Liver fat in the metabolic syndrome. J. Clin. Endocrinol. Metab. 2007, 92, 3490-3497. [CrossRef]

116. Chitturi, S.; Farrell, G.C. Fatty liver now, diabetes and heart attack later? The liver as a barometer of metabolic health. J. Gastroenterol. Hepatol. 2007, 22, 967-969. [CrossRef] [PubMed]

117. Musso, G.; Gambino, R.; Bo, S.; Uberti, B.; Biroli, G.; Pagano, G.; Cassader, M. Should nonalcoholic fatty liver disease be included in the definition of metabolic syndrome? A cross-sectional comparison with Adult Treatment Panel III criteria in nonobese nondiabetic subjects. Diabetes Care 2008, 31, 562-568. [CrossRef] [PubMed]

118. Vanni, E.; Bugianesi, E.; Kotronen, A.; De Minicis, S.; Yki-Järvinen, H.; Svegliati-Baroni, G. From the metabolic syndrome to NAFLD or vice versa? Dig. Liver Dis. 2010, 42, 320-330. [CrossRef] [PubMed]

119. Hamaguchi, M.; Takeda, N.; Kojima, T.; Ohbora, A.; Kato, T.; Sarui, H.; Fukui, M.; Nagata, C.; Takeda, J. Identification of individuals with non-alcoholic fatty liver disease by the diagnostic criteria for the metabolic syndrome. World J. Gastroenterol. 2012, 18, 1508-1516. [CrossRef]

120. Zhang, Y.; Zhang, T.; Zhang, C.; Tang, F.; Zhong, N.; Li, H.; Song, X.; Lin, H.; Liu, Y.; Xue, F. Identification of reciprocal causality between non-alcoholic fatty liver disease and metabolic syndrome by a simplified Bayesian network in a Chinese population. BMJ Open 2015, 5, e008204. [CrossRef]

121. Yki-Järvinen, H. Non-alcoholic fatty liver disease as a cause and a consequence of metabolic syndrome. Lancet. Diabetes Endocrinol. 2014, 2, 901-910. [CrossRef]

122. Ma, J.; Hwang, S.J.; Pedley, A.; Massaro, J.M.; Hoffmann; Chung, R.T.; Benjamin, E.J.; Levy, D.; Fox, C.S.; Long, M.T. Bi-directional analysis between fatty liver and cardiovascular disease risk factors. J. Hepatol. 2017, 66, 390-397. [CrossRef]

123. Hanley, A.J.; Williams, K.; Festa, A.; Wagenknecht, L.E.; D'Agostino, R.B., Jr.; Haffner, S.M. Liver markers and development of the metabolic syndrome: The insulin resistance atherosclerosis study. Diabetes 2005, 54, 3140-3147. [CrossRef]

124. Nakanishi, N.; Suzuki, K.; Tatara, K. Serum-glutamyltransferase and risk of metabolic syndrome and type 2 diabetes in middle-aged Japanese men. Diabetes Care 2004, 27, 1427-1432. [CrossRef]

125. Ballestri, S.; Zona, S.; Targher, G.; Romagnoli, D.; Baldelli, E.; Nascimbeni, F.; Roverato, A.; Guaraldi, G.; Lonardo, A. Nonalcoholic fatty liver disease is associated with an almost twofold increased risk of incident type 2 diabetes and metabolic syndrome. Evidence from a systematic review and meta-analysis. J. Gastroenterol. Hepatol. 2016, 31, 936-944. [CrossRef]

126. Mantovani, A.; Byrne, C.D.; Bonora, E.; Targher, G. Nonalcoholic Fatty Liver Disease and Risk of Incident Type 2 Diabetes: A Meta-analysis. Diabetes Care 2018, 41, 372-382. [CrossRef] [PubMed]

127. Riva, M.A.; Riva, E.; Spicci, M.; Strazzabosco, M.; Giovannini, M.; Cesana, G. "The city of Hepar": Rituals, gastronomy, and politics at the origins of the modern names for the liver. J. Hepatol. 2011, 55, 1132-1136. [CrossRef] [PubMed]

128. Lonardo, A.; Targher, G. From a fatty liver to a sugary blood. Dig. Liver Dis. 2018, 50, 378-380. [CrossRef] [PubMed]

129. Italian Association for the Study of the Liver (AISF). AISF position paper on nonalcoholic fatty liver disease (NAFLD): Updates and future directions. Dig. Liver Dis. 2017, 49, 471-483. [CrossRef] [PubMed]

130. Lonardo, A.; Nascimbeni, F.; Mantovani, A.; Targher, G. Hypertension, diabetes, atherosclerosis and NASH: Cause or consequence? J. Hepatol. 2018, 68, 335-352. [CrossRef] [PubMed]

131. Targher, G.; Bertolini, L.; Padovani, R.; Zenari, L.; Zoppini, G.; Falezza, G. Relation of nonalcoholic hepatic steatosis to early carotid atherosclerosis in healthy men: Role of visceral fat accumulation. Diabetes Care 2004, 27, 1498-1500. [CrossRef] [PubMed]

132. Targher, G.; Bertolini, L.; Poli, F.; Rodella, S.; Scala, L.; Tessari, R.; Zenari, L.; Falezza, G. Nonalcoholic fatty liver disease and risk of future cardiovascular events among type 2 diabetic patients. Diabetes 2005, 54, 3541-3546. [CrossRef]

133. Targher, G.; Bertolini, L.; Padovani, R.; Zoppini, G.; Zenari, L.; Falezza, G. Associations between liver histology and carotid intima-media thickness in patients with nonalcoholic fatty liver disease. Arterioscler. Thromb. Vasc. Biol. 2005, 25, 2687-2688. [CrossRef] 
134. Ampuero, J.; Gallego-Durán, R.; Romero-Gómez, M. Association of NAFLD with subclinical atherosclerosis and coronary-artery disease: Meta-analysis. Rev. Esp. Enferm. Dig. 2015, 107, 10-16.

135. Targher, G.; Byrne, C.D.; Lonardo, A.; Zoppini, G.; Barbui, C. Non-alcoholic fatty liver disease and risk of incident cardiovascular disease: A meta-analysis. J. Hepatol. 2016, 65, 589-600. [CrossRef]

136. Bugianesi, E.; Leone, N.; Vanni, E.; Marchesini, G.; Brunello, F.; Carucci, P.; Musso, A.; De Paolis, P.; Capussotti, L.; Salizzoni, M.; et al. Expanding the natural history of nonalcoholic steatohepatitis: From cryptogenic cirrhosis to hepatocellular carcinoma. Gastroenterology 2002, 123, 134-140. [CrossRef] [PubMed]

137. Marrero, J.A.; Fontana, R.J.; Su, G.L.; Conjeevaram, H.S.; Emick, D.M.; Lok, A.S. NAFLD may be a common underlying liver disease in patients with hepatocellular carcinoma in the United States. Hepatology 2002, 36, 1349-1354. [CrossRef] [PubMed]

138. Stine, J.G.; Wentworth, B.J.; Zimmet, A.; Rinella, ME.; Loomba, R.; Caldwell, S.H.; Argo, C.K. Systematic review with meta-analysis: Risk of hepatocellular carcinoma in non-alcoholic steatohepatitis without cirrhosis compared to other liver diseases. Aliment. Pharmacol. Ther. 2018, 48, 696-703. [CrossRef] [PubMed]

139. Zoller, H.; Tilg, H. Nonalcoholic fatty liver disease and hepatocellular carcinoma. Metabolism 2016, 65, 1151-1160. [CrossRef]

140. Younes, R.; Bugianesi, E. Should we undertake surveillance for HCC in patients with NAFLD? J. Hepatol. 2018, 68, 326-334. [CrossRef]

141. Sørensen, H.T.; Mellemkjaer, L.; Jepsen, P.; Thulstrup, A.M.; Baron, J.; Olsen, J.H.; Vilstrup, H. Risk of cancer in patients hospitalized with fatty liver: A Danish cohort study. J. Clin. Gastroenterol. 2003, 36, 356-359. [CrossRef]

142. Sanna, C.; Rosso, C.; Marietti, M.; Bugianesi, E. Non-Alcoholic Fatty Liver Disease and Extra-Hepatic Cancers. Int. J. Mol. Sci. 2016, 17, 717. [CrossRef]

143. Ballestri, S.; Mantovani, A.; Nascimbeni, F.; Lugari, S.; Lonardo, A. Extra-hepatic manifestations and complications of nonalcoholic fatty liver disease. Future Med. Chem. 2019, 11, 2171-2192. [CrossRef]

144. Allen, A.M.; Hicks, S.B.; Mara, K.C.; Larson, J.J.; Therneau, T.M. The risk of incident extrahepatic cancers is higher in non-alcoholic fatty liver disease than obesity-A longitudinal cohort study. J. Hepatol. 2019, 71, 1229-1236. [CrossRef]

145. Mantovani, A.; Dauriz, M.; Byrne, C.D.; Lonardo, A.; Zoppini, G.; Bonora, E.; Targher, G. Association between nonalcoholic fatty liver disease and colorectal tumours in asymptomatic adults undergoing screening colonoscopy: A systematic review and meta-analysis. Metabolism 2018, 87, 1-12. [CrossRef]

146. Kim, M.C.; Park, J.G.; Jang, B.I.; Lee, H.J.; Lee, W.K. Liver fibrosis is associated with risk for colorectal adenoma in patients with nonalcoholic fatty liver disease. Medicine 2019, 98, e14139. [CrossRef] [PubMed]

147. Lonardo, A.; Roncucci, L. The "obese liver" and gastrointestinal cancer risk. Transl. Gastroenterol. Hepatol. 2020, 5, 44. [CrossRef] [PubMed]

148. Farrell, G.C.; Chitturi, S.; Lau, G.K.; Sollano, J.D. Asia-Pacific Working Party on NAFLD. Guidelines for the assessment and management of non-alcoholic fatty liver disease in the Asia-Pacific region: Executive summary. J. Gastroenterol. Hepatol. 2007, 22, 775-777. [CrossRef] [PubMed]

149. Chitturi, S.; Farrell, G.C.; Hashimoto, E.; Saibara, T.; Lau, G.K.; Sollano, J.D. Non-alcoholic fatty liver disease in the Asia-Pacific region: Definitions and overview of proposed guidelines. J. Gastroenterol. Hepatol. 2007, 22, 778-787. [CrossRef]

150. Chalasani, N.; Younossi, Z.; Lavine, J.E.; Diehl, A.M.; Brunt, E.M.; Cusi, K.; Charlton, M.; Sanyal, AJ. The diagnosis and management of non-alcoholic fatty liver disease: Practice Guideline by the American Association for the Study of Liver Diseases, American College of Gastroenterology, and the American Gastroenterological Association. Hepatology 2012, 55, 2005-2023. [CrossRef]

151. Guyatt, G.H.; Oxman, A.D.; Vist, G.E.; Kunz, R.; Falck-Ytter, Y.; Alonso-Coello, P.; Schünemann, H.J.; GRADE Working Group. GRADE: An emerging consensus on rating quality of evidence and strength of recommendations. BMJ 2008, 336, 924-926. [CrossRef]

152. Review Team; LaBrecque, D.R.; Abbas, Z.; Anania, F.; Ferenci, P.; Khan, A.G.; Goh, K.L.; Hamid, S.S.; Isakov, V.; Lizarzabal, M.; et al. World Gastroenterology Organisation global guidelines: Nonalcoholic fatty liver disease and nonalcoholic steatohepatitis. J. Clin. Gastroenterol. 2014, 48, 467-473. [CrossRef] 
153. Loria, P.; Adinolfi, L.E.; Bellentani, S.; Bugianesi, E.; Grieco, A.; Fargion, S.; Gasbarrini, A.; Loguercio, C.; Lonardo, A.; Marchesini, G.; et al. Practice guidelines for the diagnosis and management of nonalcoholic fatty liver disease. A decalogue from the Italian Association for the Study of the Liver (AISF) Expert Committee. Dig. Liver. Dis. 2010, 42, 272-282. [CrossRef]

154. Fan, J.G.; Jia, J.D.; Li, Y.M.; Wang, B.Y.; Lu, L.G.; Shi, J.P.; Chan, L.Y.; Chinese Association for the Study of Liver Disease. Guidelines for the diagnosis and management of nonalcoholic fatty liver disease. J. Dig. Dis. 2011, 12, 38-44, Update in Chin. J. Hepatol. 2010, 18, 163-166. [CrossRef]

155. Korean Association for the Study of the Liver. KASL clinical practice guidelines: Management of nonalcoholic fatty liver disease The Korean Association for the Study of the Liver (KASL). Clin. Mol. Hepatol. 2013, 19, 325-348. [CrossRef]

156. Watanabe, S.; Hashimoto, E.; Ikejima, K.; Uto, H.; Ono, M.; Sumida, Y.; Seike, M.; Takei, Y.; Takehara, T.; Tokushige, K.; et al. Evidence-based clinical practice guidelines for nonalcoholic fatty liver disease/nonalcoholic steatohepatitis. J. Gastroenterol. 2015, 50, 364-377. [CrossRef] [PubMed]

157. European Association for the Study of the Liver (EASL); European Association for the Study of Diabetes (EASD); European Association for the Study of Obesity (EASO). EASL-EASD-EASO Clinical Practice Guidelines for the management of non-alcoholic fatty liver disease. J. Hepatol. 2016, 64, 1388-1402. [CrossRef] [PubMed]

158. Wong, V.W.; Chan, W.K.; Chitturi, S.; Chawla, Y.; Dan, Y.Y.; Duseja, A.; Fan, J.; Goh, K.L.; Hamaguchi, M.; Hashimoto, E.; et al. Asia-Pacific Working Party on Non-alcoholic Fatty Liver Disease guidelines 2017-Part 1: Definition, risk factors and assessment. J. Gastroenterol. Hepatol. 2018, 33, 70-85. [CrossRef] [PubMed]

159. Chitturi, S.; Wong, V.W.; Chan, W.K.; Wong, G.L.; Wong, S.K.; Sollano, J.; Ni, Y.H.; Liu, C.J.; Lin, Y.C.; Lesmana, L.A.; et al. The Asia-Pacific Working Party on Non-alcoholic Fatty Liver Disease guidelines 2017-Part 2: Management and special groups. J. Gastroenterol. Hepatol. 2018, 33, 86-98. [CrossRef]

160. Chalasani, N.; Younossi, Z.; Lavine, J.E.; Charlton, M.; Cusi, K.; Rinella, M.; Harrison, S.A.; Brunt, E.M.; Sanyal, A.J. The diagnosis and management of nonalcoholic fatty liver disease: Practice guidance from the American Association for the Study of Liver Diseases. Hepatology 2018, 67, 328-357. [CrossRef]

161. National Institute for Health and Care Excellence (UK) Non-Alcoholic Fatty Liver Disease: Assessment and Management. Available online: https://www.nice.org.uk/guidance/ng49/resources/nonalcoholic-fatty-liverdisease-nafld-assessment-and-management-pdf-1837461227461 (accessed on 2 July 2020).

162. Aller, R.; Fernández-Rodríguez, C.; Lo Iacono, O.; Bañares, R.; Abad, J.; Carrión, J.A.; García-Monzón, C.; Caballería, J.; Berenguer, M.; Rodríguez-Perálvarez, M.; et al. Consensus document. Management of non-alcoholic fatty liver disease (NAFLD). Clin. Pract. Guidel. 2018, 41, 328-349, Correction in 2018, 41, 475-476.

163. Alswat, K.A.; Fallatah, H.I.; Al-Judaibi, B.; Elsiesy, H.A.; Al-Hamoudi, W.K.; Qutub, A.N.; Alturaify, N.; Al-Osaimi, A. Position statement on the diagnosis and management of non-alcoholic fatty liver disease. Saudi. Med. J. 2019, 40, 531-540. [CrossRef]

164. Nascimbeni, F.; Pais, R.; Bellentani, S.; Day, C.P.; Ratziu, V.; Loria, P.; Lonardo, A. From NAFLD in clinical practice to answers from guidelines. J. Hepatol. 2013, 59, 859-871. [CrossRef]

165. Leoni, S.; Tovoli, F.; Napoli, L.; Serio, I.; Ferri, S.; Bolondi, L. Current guidelines for the management of non-alcoholic fatty liver disease: A systematic review with comparative analysis. World J. Gastroenterol. 2018, 24, 3361-3373. [CrossRef]

166. Zhu, J.Z.; Hollis-Hansen, K.; Wan, X.Y.; Fei, S.J.; Pang, X.L.; Meng, F.D.; Yu, C.H.; Li, Y.M. Clinical guidelines of non-alcoholic fatty liver disease: A systematic review. World J. Gastroenterol. 2016, 22, 8226-8233. [CrossRef]

167. Anderson, E.L.; Howe, L.D.; Jones, H.E.; Higgins, J.P.; Lawlor, D.A.; Fraser, A. The Prevalence of Non-Alcoholic Fatty Liver Disease in Children and Adolescents: A Systematic Review and Meta-Analysis. PLoS ONE 2015, 10, e0140908. [CrossRef] [PubMed]

168. Goldner, D.; Lavine, J.E. Nonalcoholic Fatty Liver Disease in Children: Unique Considerations and Challenges. Gastroenterology 2020, 158, 1967-1983. [CrossRef] [PubMed]

169. Vos, M.B.; Abrams, S.H.; Barlow, S.E.; Caprio, S.; Daniels, S.R.; Kohli, R.; Mouzaki, M.; Sathya, P.; Schwimmer, J.B.; Sundaram, S.S.; et al. NASPGHAN Clinical Practice Guideline for the Diagnosis and Treatment of Nonalcoholic Fatty Liver Disease in Children: Recommendations from the Expert Committee on NAFLD (ECON) and the North American Society of Pediatric Gastroenterology, Hepatology and Nutrition (NASPGHAN). J. Pediatr. Gastroenterol. Nutr. 2017, 64, 319-334. [PubMed] 
170. Day, C.P.; James, O.F. Steatohepatitis: A tale of two "hits"? Gastroenterology 1998, 114, 842-845. [CrossRef]

171. Tilg, H.; Moschen, A.R. Evolution of inflammation in nonalcoholic fatty liver disease: The multiple parallel hits hypothesis. Hepatology 2010, 52, 1836-1846. [CrossRef] [PubMed]

172. Buzzetti, E.; Pinzani, M.; Tsochatzis, E.A. The multiple-hit pathogenesis of non-alcoholic fatty liver disease (NAFLD). Metabolism 2016, 65, 1038-1048. [CrossRef]

173. Diehl, A.M.; Day, C. Nonalcoholic Steatohepatitis. N. Engl. J. Med. 2018, 378, 781. [CrossRef]

174. Sanyal, A.J. Past, present and future perspectives in nonalcoholic fatty liver disease. Nat. Rev. Gastroenterol. Hepatol. 2019, 16, 377-386. [CrossRef]

175. Chakravarthy, M.V.; Neuschwander-Tetri, B.A. The metabolic basis of nonalcoholic steatohepatitis. Endocrinol. Diab. Metab. 2020, 00, e00112. [CrossRef]

176. Caldwell, S.H.; Swerdlow, R.H.; Khan, E.M.; Iezzoni, J.C.; Hespenheide, E.E.; Parks, J.K.; Parker, W.D., Jr. Mitochondrial abnormalities in non-alcoholic steatohepatitis. J. Hepatol. 1999, 31, 430-434. [CrossRef]

177. Leclercq, I.A.; Farrell, G.C.; Field, J.; Bell, D.R.; Gonzalez, F.J.; Robertson, G.R. CYP2E1 and CYP4A as microsomal catalysts of lipid peroxides in murine nonalcoholic steatohepatitis. J. Clin. Investig. 2000, 105, 1067-1075. [CrossRef] [PubMed]

178. Robertson, G.; Leclercq, I.; Farrell, G.C. Nonalcoholic steatosis and steatohepatitis. II. Cytochrome P-450 enzymes and oxidative stress. Am. J. Physiol. Gastrointest. Liver Physiol. 2001, 281, G1135-G1139. [CrossRef] [PubMed]

179. Sanyal, A.J.; Campbell-Sargent, C.; Mirshahi, F.; Rizzo, W.B.; Contos, M.J.; Sterling, R.K.; Luketic, V.A.; Shiffman, M.L.; Clore, J.N. Nonalcoholic steatohepatitis: Association of insulin resistance and mitochondrial abnormalities. Gastroenterology 2001, 120, 1183-1192. [CrossRef] [PubMed]

180. Paradis, V.; Perlemuter, G.; Bonvoust, F.; Dargere, D.; Parfait, B.; Vidaud, M.; Conti, M.; Huet, S.; Ba, N.; Buffet, C.; et al. High glucose and hyperinsulinemia stimulate connective tissue growth factor expression: A potential mechanism involved in progression to fibrosis in nonalcoholic steatohepatitis. Hepatology 2001, 34, 738-744. [CrossRef] [PubMed]

181. Crespo, J.; Cayón, A.; Fernández-Gil, P.; Hernández-Guerra, M.; Mayorga, M.; Domínguez-Díez, A.; Fernández-Escalante, J.C.; Pons-Romero, F. Gene expression of tumor necrosis factor alpha and TNF-receptors, p55 and p75, in nonalcoholic steatohepatitis patients. Hepatology 2001, 34, 1158-1163. [CrossRef]

182. Marra, F.; Aleffi, S.; Bertolani, C.; Petrai, I.; Vizzutti, F. Review article: The pathogenesis of fibrosis in non-alcoholic steatohepatitis. Aliment. Pharmacol. Ther. 2005, 22, 44-47. [CrossRef] [PubMed]

183. Caldwell, S.H.; de Freitas, L.A.; Park, S.H.; Moreno, M.L.V.; Redick, J.A.; Davis, C.A.; Sisson, B.J.; Patrie, J.T.; Cotrim, H.; Argo, C.K.; et al. Intramitochondrial crystalline inclusions in nonalcoholic steatohepatitis. Hepatology 2009, 49, 1888-1895. [CrossRef]

184. Targher, G.; Bertolini, L.; Scala, L.; Poli, F.; Zenari, L.; Falezza, G. Decreased plasma adiponectin concentrations are closely associated with nonalcoholic hepatic steatosis in obese individuals. Clin. Endocrinol. 2004, 61, 700-703. [CrossRef]

185. Kaser, S.; Moschen, A.; Cayon, A.; Kaser, A.; Crespo, J.; Pons-Romero, F.; Ebenbichler, C.-F.; Patsch, J.R.; Tilg, H. Adiponectin and its receptors in non-alcoholic steatohepatitis. Gut 2005, 54, 117-121. [CrossRef]

186. Pagano, C.; Soardo, G.; Esposito, W.; Fallo, F.; Basan, L.; Donnini, D.; Federspil, G.; Sechi, L.A.; Vettor, R. Plasma adiponectin is decreased in nonalcoholic fatty liver disease. Eur. J. Endocrinol. 2005, 152, 113-118. [CrossRef]

187. Vuppalanchi, R.; Marri, S.; Kolwankar, D.; Considine, R.V.; Chalasani, N. Is adiponectin involved in the pathogenesis of nonalcoholic steatohepatitis? A preliminary human study. J. Clin. Gastroenterol. 2005, 39, 237-242. [CrossRef] [PubMed]

188. Bugianesi, E.; Pagotto, U.; Manini, R.; Vanni, E.; Gastaldelli, A.; de Iasio, R.; Gentilcore, E.; Natale, S.; Cassader, M.; Rizzetto, M.; et al. Plasma adiponectin in nonalcoholic fatty liver is related to hepatic insulin resistance and hepatic fat content, not to liver disease severity. J. Clin. Endocrinol. Metab. 2005, 90, 3498-3504. [CrossRef] [PubMed]

189. Targher, G.; Bertolini, L.; Rodella, S.; Zoppini, G.; Scala, L.; Zenari, L.; Falezza, G. Associations between plasma adiponectin concentrations and liver histology in patients with nonalcoholic fatty liver disease. Clin. Endocrinol. 2006, 64, 679-683. [CrossRef] [PubMed] 
190. Younossi, Z.M.; Gorreta, F.; Ong, J.P.; Schlauch, K.; Del Giacco, L.; Elariny, H.; Van Meter, A.; Younoszai, A.; Goodman, Z.; Baranova, A.; et al. Hepatic gene expression in patients with obesity-related non-alcoholic steatohepatitis. Liver Int. 2005, 25, 760-771. [CrossRef] [PubMed]

191. Younossi, Z.M.; Baranova, A.; Ziegler, K.; Del Giacco, L.; Schlauch, K.; Born, T.L.; Elariny, H.; Gorreta, F.; VanMeter, A.; Younoszai, A.; et al. A genomic and proteomic study of the spectrum of nonalcoholic fatty liver disease. Hepatology 2005, 42, 665-674. [CrossRef] [PubMed]

192. Baffy, G. Uncoupling protein-2 and non-alcoholic fatty liver disease. Front. Biosci. 2005, 10, $2082-2096$. [CrossRef]

193. Puri, P.; Baillie, R.A.; Wiest, M.M.; Mirshahi, F.; Choudhury, J.; Cheung, O.; Sargeant, C.; Contos, M.J.; Sanyal, A.J. A lipidomic analysis of nonalcoholic fatty liver disease. Hepatology 2007, 46, 1081-1090. [CrossRef]

194. Puri, P.; Wiest, M.M.; Cheung, O.; Mirshahi, F.; Sargeant, C.; Min, H.K.; Contos, M.J.; Sterling, R.K.; Fuchs, M.; Zhou, H.; et al. The plasma lipidomic signature of nonalcoholic steatohepatitis. Hepatology 2009, 50, 1827-1838. [CrossRef]

195. Fon Tacer, K.; Rozman, D. Nonalcoholic Fatty liver disease: Focus on lipoprotein and lipid deregulation. J. Lipids 2011, 2011, 783976. [CrossRef]

196. Bell, L.N.; Molleston, J.P.; Morton, M.J.; Klipsch, A.; Saxena, R.; Vuppalanchi, R.; Chalasani, N. Hepatic lipid peroxidation and cytochrome P-450 2E1 in pediatric nonalcoholic fatty liver disease and its subtypes. J. Clin. Gastroenterol. 2011, 45, 800-807. [CrossRef]

197. Feldstein, A.E.; Gores, G.J. Apoptosis in alcoholic and nonalcoholic steatohepatitis. Front. Biosci. 2005, 10, 3093-3099. [CrossRef] [PubMed]

198. Farrell, G.C.; Larter, C.Z.; Hou, J.Y.; Zhang, R.H.; Yeh, M.H.; Williams, J.; dela Pena, A.; Rona, F.; Osvath, S.R.; Brooling, J.; et al. Apoptosis in experimental NASH is associated with p53 activation and TRAIL receptor expression. J. Gastroenterol. Hepatol. 2009, 24, 443-452. [CrossRef] [PubMed]

199. Malhi, H.; Gores, G.J. Molecular mechanisms of lipotoxicity in nonalcoholic fatty liver disease. Semin. Liver Dis. 2008, 28, 360-369. [CrossRef] [PubMed]

200. Gentile, C.L.; Pagliassotti, M.J. The role of fatty acids in the development and progression of nonalcoholic fatty liver disease. J. Nutr. Biochem. 2008, 19, 567-576. [CrossRef] [PubMed]

201. Kallwitz, E.R.; McLachlan, A.; Cotler, S.J. Role of peroxisome proliferators-activated receptors in the pathogenesis and treatment of nonalcoholic fatty liver disease. World J. Gastroenterol. 2008, 14, 22-28. [CrossRef] [PubMed]

202. George, J.; Liddle, C. Nonalcoholic fatty liver disease: Pathogenesis and potential for nuclear receptors as therapeutic targets. Mol. Pharm. 2008, 5, 49-59. [CrossRef] [PubMed]

203. Grønbaek, H.; Thomsen, K.L.; Rungby, J.; Schmitz, O.; Vilstrup, H. Role of nonalcoholic fatty liver disease in the development of insulin resistance and diabetes. Expert Rev. Gastroenterol. Hepatol. 2008, 2, 705-711. [CrossRef]

204. Kumashiro, N.; Erion, D.M.; Zhang, D.; Kahn, M.; Beddow, S.A.; Chu, X.; Still, C.D.; Gerhard, G.S.; Han, X.; Dziura, J.; et al. Cellular mechanism of insulin resistance in nonalcoholic fatty liver disease. Proc. Natl. Acad. Sci. USA 2011, 108, 16381-16385. [CrossRef]

205. Baffy, G. Kupffer cells in non-alcoholic fatty liver disease: The emerging view. J. Hepatol. 2009, 51, $212-223$. [CrossRef]

206. Miele, L.; Valenza, V.; La Torre, G.; Montalto, M.; Cammarota, G.; Ricci, R.; Mascianà, R.; Forgione, A.; Gabrieli, M.L.; Perotti, G.; et al. Increased intestinal permeability and tight junction alterations in nonalcoholic fatty liver disease. Hepatology 2009, 49, 1877-1887. [CrossRef]

207. Syn, W.K.; Jung, Y.; Omenetti, A.; Abdelmalek, M.; Guy, C.D.; Yang, L.; Wang, J.; Witek, R.P.; Fearing, C.M.; Pereira, T.A.; et al. Hedgehog-mediated epithelial-to-mesenchymal transition and fibrogenic repair in nonalcoholic fatty liver disease. Gastroenterology 2009, 137, 1478-1488. [CrossRef] [PubMed]

208. Cheung, O.; Sanyal, A.J. Role of microRNAs in non-alcoholic steatohepatitis. Curr. Pharm. Des. 2010, 16, 1952-1957. [CrossRef] [PubMed]

209. Van Rooyen, D.M.; Farrell, G.C. SREBP-2: A link between insulin resistance, hepatic cholesterol, and inflammation in NASH. J. Gastroenterol. Hepatol. 2011, 26, 789-792. [CrossRef] [PubMed]

210. Van Rooyen, D.M.; Larter, C.Z.; Haigh, W.G.; Yeh, M.M.; Ioannou, G.; Kuver, R.; Lee, S.P.; Teoh, N.C.; Farrell, G.C. Hepatic free cholesterol accumulates in obese, diabetic mice and causes nonalcoholic steatohepatitis. Gastroenterology 2011, 141, 1393-1403. [CrossRef] 
211. Van Rooyen, D.M.; Gan, L.T.; Yeh, M.M.; Haigh, W.G.; Larter, C.Z.; Ioannou, G.; Teoh, N.C.; Farrell, G.C. Pharmacological cholesterol lowering reverses fibrotic NASH in obese, diabetic mice with metabolic syndrome. J. Hepatol. 2013, 59, 144-152. [CrossRef]

212. Pirola, C.J.; Gianotti, T.F.; Burgueño, A.L.; Rey-Funes, M.; Loidl, C.F.; Mallardi, P.; San Martino, J.; Castaño, G.O.; Sookoian., S. Epigenetic modification of liver mitochondrial DNA is associated with histological severity of nonalcoholic fatty liver disease. Gut 2013, 62, 1356-1363. [CrossRef]

213. Kasumov, T.; Li, L.; Li, M.; Gulshan, K.; Kirwan, J.P.; Liu, X.; Previs, S.; Willard, B.; et al. Ceramide as a mediator of non-alcoholic Fatty liver disease and associated atherosclerosis. PLOS ONE 2015, 10, e0126910. [CrossRef]

214. Kutlu, O.; Kaleli, H.N.; Ozer, E. Molecular Pathogenesis of Nonalcoholic Steatohepatitis-(NASH-) Related Hepatocellular Carcinoma. Can. J. Gastroenterol. Hepatol. 2018, 2018, 8543763. [CrossRef]

215. Hernández, A.; Arab, J.P.; Reyes, D.; Lapitz, A.; Moshage, H.; Bañales, J.M.; Arrese, M. Extracellular Vesicles in NAFLD/ALD: From Pathobiology to Therapy. Cells 2020, 9, 817. [CrossRef]

216. Younossi, Z.M.; Rinella, M.E.; Sanyal, A.; Harrison, S.A.; Brunt, E.; Goodman, Z.; Cohen, D.E.; Loomba, R. From NAFLD to MAFLD: Implications of a premature change in terminology. Hepatology 2020, 10, 1002. [CrossRef]

217. Lin, S.; Huang, J.; Wang, M.; Kumar, R.; Liu, Y.; Liu, S.; Wu, Y.; Wang, X.; Zhu, Y. Comparison of MAFLD and NAFLD diagnostic criteria in real world. Liver Int. 2020, 10, 1111, published online ahead of print, 2020. [CrossRef] [PubMed]

218. Zhang, T.S.; Qin, H.L.; Wang, T.; Li, H.T.; Li, H.; Xia, S.H.; Xiang, X.H. Bibliometric analysis of top 100 cited articles in nonalcoholic fatty liver disease research. World J. Hepatol. 2016, 8, 1478-1488. [CrossRef] [PubMed]

219. David, A.R.; Kershaw, A.; Heagerty, A. The art of medicine. Atherosclerosis and diet in ancient Egyp. Lancet 2010, 375, 718-719. [CrossRef]

220. Karamanou, M.; Protogerou, A.; Tsoucalas, G.; Androutsos, G.; Poulakou-Rebelakou, E. Milestones in the history of diabetes mellitus: The main contributors. World J. Diabetes 2016, 7, 1-7. [CrossRef] [PubMed]

221. Lim, U.; Monroe, K.R.; Buchthal, S.; Fan, B.; Cheng, I.; Kristal, B.S.; Lampe, J.W.; Hullar, M.A.; Franke, A.A.; Stram, D.O.; et al. Propensity for Intra-abdominal and Hepatic Adiposity Varies Among Ethnic Groups. Gastroenterology 2019, 156, 966-975. [CrossRef]

(C) 2020 by the authors. Licensee MDPI, Basel, Switzerland. This article is an open access article distributed under the terms and conditions of the Creative Commons Attribution (CC BY) license (http://creativecommons.org/licenses/by/4.0/). 